\title{
Las portadas de los prioratos cluniacenses de Tierra de Campos en tiempos de Alfonso VI: una iconografía de corte monástico para una manifestación pública
}

\author{
Marta Poza Yagüe \\ Universidad Complutense de Madrid
}

En la Capilla de El Salvador de la catedral compostelana, un capitel efigiando al monarca Alfonso VI conmemora el comienzo de las obras de la nueva basílica, en 1075, según constata la inscripción que acompaña a la imagen: REGNANTE PRINCIPE ADEFONSO CONSTRUCTUM OPUS (fig. 1). La talla, además de proporcionarnos una representación contemporánea del protagonista de este volumen -y precisamente por ello-, nos ha parecido el frontispicio idóneo para abordar algunos aspectos vinculados con el panorama de la plástica románica del momento. Y es que al amparo de las grandes fábricas catedralicias y monasteriales, así como de los templos protegidos por la familia real, entre fines de la undécima centuria y los primeros años de la siguiente, se desarrolla en el reino castellanoleonés una producción escultórica cuya calidad difícilmente será superada en las décadas siguientes. Junto a talleres foráneos que importan motivos y esquemas ensayados con anterioridad en las regiones del Centro y Oeste de Francia -como es el caso del ejemplo propuesto-, despunta la desbordante creatividad de una corriente antiquizante cuya procedencia y difusión, desde Frómista a Jaca, o a la inversa, aún divide la opinión de los especialistas ${ }^{1}$.

Pero no será la cuestión estilística la que centre nuestro trabajo. Esta escultura se despliega en los capiteles del interior de los edificios, en los canecillos de las cornisas, pero también gana para sí ahora ese ámbito publicitario privilegiado que son las portadas. De estos momentos datan los primeros ingresos monumentalizados en el territorio. Ahora bien, ¿están concebidos sus programas 


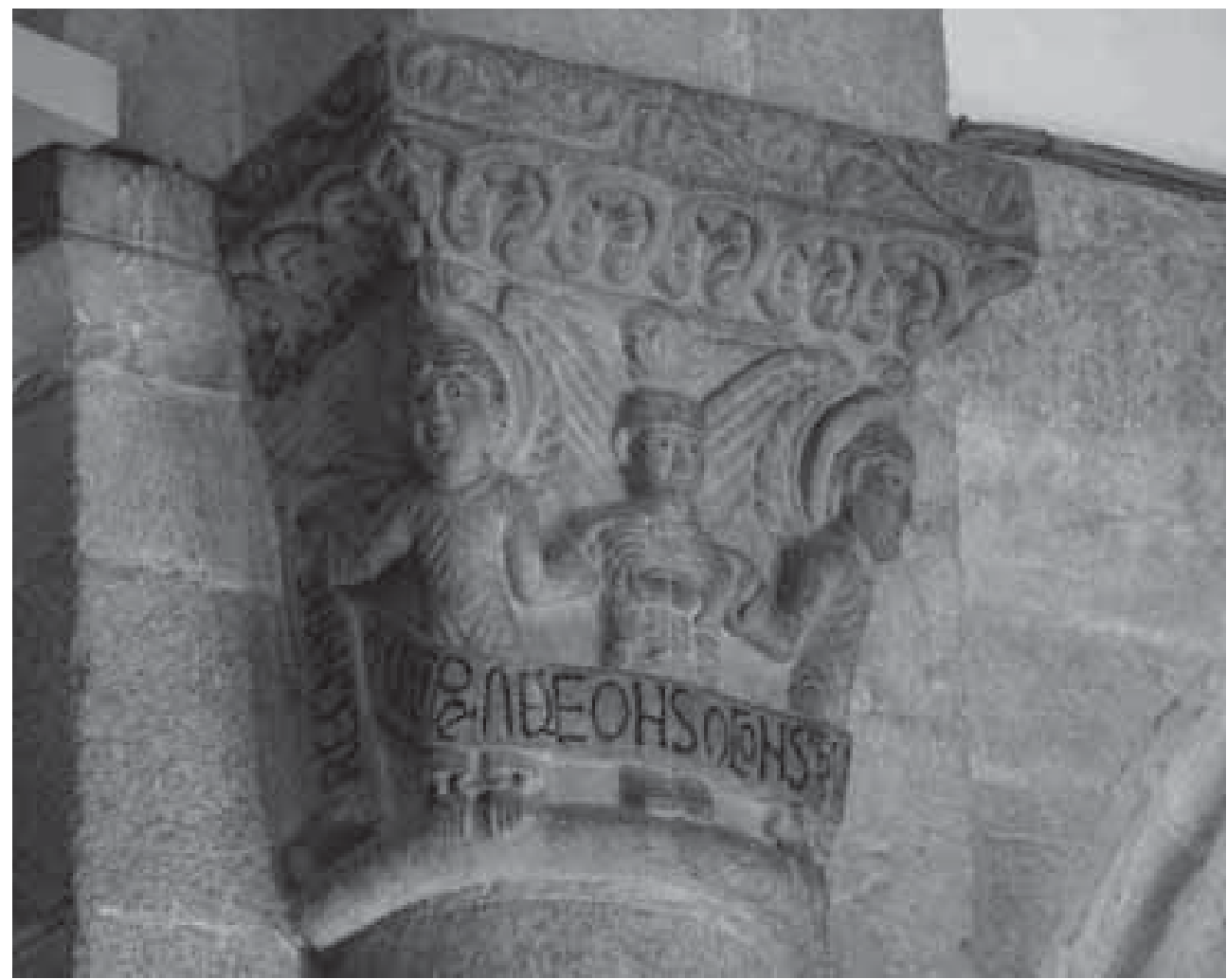

Fig. 1. REGNANTE PRINCIPE ADEFONSO CONSTRUCTUM OPUS. Santiago de Compostela. Capilla de El Salvador (Foto A. García Omedes).

para un público amplio, como comúnmente se afirma?, o, al contrario, ¿deben restringirse sus destinatarios a aquéllos que los patrocinan o que son su auditorio preferente?. Esta última parece ser la respuesta más apropiada para los accesos castellanoleoneses más tempranos.

Teniendo en cuenta cuál pudo ser el paisaje visual más familiar a Alfonso VI, con la excepción de la basílica isidoriana a la que voluntariamente pareció dar la espalda, estas primeras portadas historiadas se concentran en un contado número de edificios relativamente próximos, sitos en Tierra de Campos, afectados de forma más o menos directa por el proceso definido hace ya varios años como de colonización cluniacense y que tuvo como protagonistas a los monjes negros llegados de allende los Pirineos. Encargados de auspiciar el cambio de las antiguas comunidades monásticas a la Regla Benedictina, así como responsables de la sustitución de la vieja liturgia hispana por el Rito Gregoriano, ambos conceptos hibridarán de forma magistral en las imágenes de acceso a sus templos en los que los diseños, lejos de perseguir de modo inmediato el adoctrinamiento del fiel, se convertirán en modelo de vita claustralis y exemplum monachorum. 


\section{La portada occidental de San Zoilo de Carrión de los Condes: cuando la narración bíblica se convierte en ejemplo de vita claustralis}

En 1076, Doña Teresa, viuda del conde del lugar Gómez Díaz, dona junto a sus descendientes a la abadía borgoñona de Cluny un antiguo cenobio del que habían sido patronos durante gran parte del siglo XI, y en el que establecerían su panteón funerario. Éste, surgido bajo la advocación de San Juan Bautista, fue puesto posteriormente bajo la titularidad de San Zoilo tras la llegada de las reliquias del mártir hispanorromano ( $\mathrm{ca}$. 1044), trasladadas desde Córdoba a Carrión por Fernando, primogénito de los condes. De lo que fue la iglesia plenorrománica, levantada en estas décadas finales de la undécima centuria, apenas se conocían escasos restos materiales hasta que, a mediados de agosto de 1993, salió a la luz la portada occidental, uno de los primeros testimonios de esta manifestación en la provincia, que había permanecido oculta hasta entonces al haber sido tapiada durante las obras de remodelación que sufrió el templo durante los siglos XVI y XVII ${ }^{2}$.

Es una sencilla estructura que aprovecha para su derrame el espesor del muro, integrada por doble arquivolta cuyas roscas de medio punto voltean sobre otras tantas columnas acodilladas por jamba. Éstas, con basas áticas de escocias recorridas por bolas, tienen fustes monolíticos de mármol, al parecer antiguas piezas romanas reaprovechadas. Sobre ellos cargan sendos capiteles figurados, rematados a su vez por cimacios con decoraciones vegetales de esquemáticas palmetas y roleos que cobijan en su interior hojas abiertas (fig. 2). Con una cronología próxima al 1100, en las cestas de la derecha se desarrolla un tema sin demasiada fortuna en la plástica románica peninsular, el episodio de la Burra de Balaam (Núm. 22, 21-36) (fig. 3 ), del que tan sólo se constatan otros dos ejemplos más o menos contemporáneos al carrionés, uno en el Panteón Real de San Isidoro, el otro en la portada meridional de la catedral de Jaca, junto con un tercero, más tardío y de menor calidad, en la portada soriana de Berzosa.

El más interno (fig. 4) figura el momento preciso en el que el Ángel del Señor, blandiendo una espada con la mano derecha, intercepta el camino del adivino

2 De la arquitectura del enclave se ha ocupado sobradamente José Luis Senra, incluso en su colaboración en este mismo volumen. Por ello, remitimos a la bibliografía proporcionada por él para todo lo relativo al conocimiento de su fábrica, limitándonos a señalar aquellos títulos que se refieran de forma específica al ingreso que es objeto de nuestro estudio. Así, fue él quien se hizo rápidamente eco de la aparición de los restos de la portada occidental en el verano de 1993, dándolos a conocer al año siguiente: J. L. SENRA GABRIEL y GALÁN, "La portada occidental recientemente descubierta en el Monasterio de San Zoilo de Carrión de los Condes", Archivo Español de Arte, no 265 (1994), pp. 57-72, e incidiendo sobre sus aspectos estilísticos en ID., "Algunas notas sobre la desaparecida iglesia románica del priorato cluniacense de Carrión de los Condes", Actas del III Congreso de Historia de Palencia (Palencia 30 marzo - 1 abril, 1995), Palencia, 19951996, vol. IV, pp. 439-451. Entre ambos trabajos había visto también la luz, con idéntico propósito, el artículo de J. CAstán LAnASPa, "Una portada románica con capiteles historiados en Carrión de los Condes (Palencia)", Estudios de Arte. Homenaje al Profesor Martín González, Valladolid, 1995, pp. 305-310. 


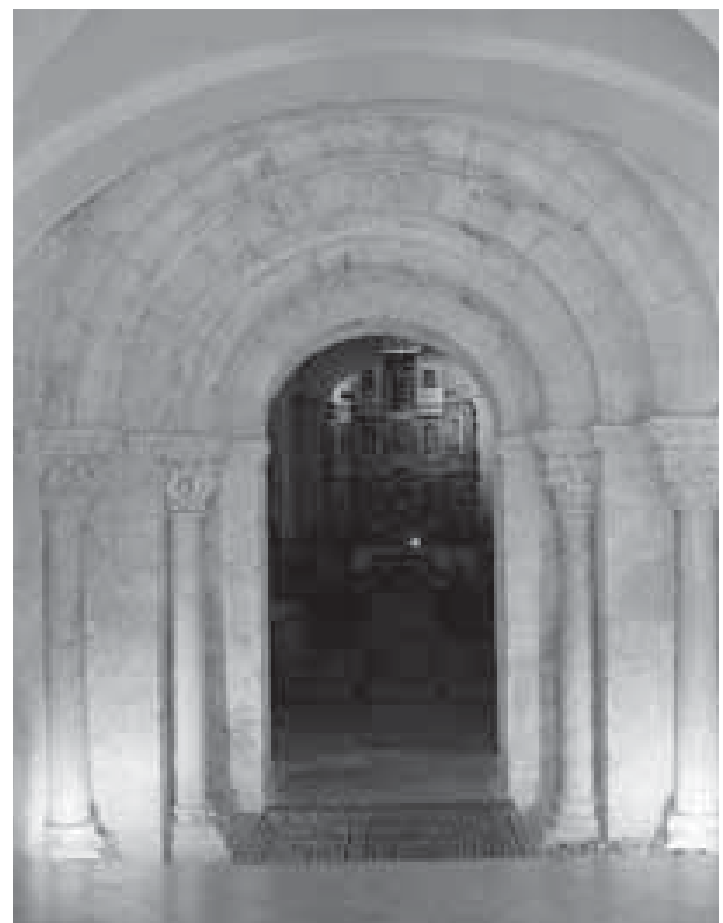

Fig. 2. Carrión de los Condes. Monasterio de San Zoilo. Portada Occidental.
Balaam quien, comisionado por Balak, rey de Moab, se dirige a maldecir a los israelitas que acaban de penetrar en sus territorios, procedentes de Egipto, para reconvertirlos a la idolatría. En un primer momento, el emisario divino sólo es percibido por el animal que detiene bruscamente su marcha (movimiento insinuado por la posición del cuerpo de la burra con la cabeza ligeramente levantada y retrasada, y con los cuartos delanteros, uno muy rígido, como posado a la fuerza, y el otro todavía en el aire), motivo por el que el jinete la castiga golpeándola tres veces (la fusta, hoy perdida, podría estar sujeta por el brazo izquierdo, también mutilado). Milagrosamente, la burra comienza a hablar recriminando a su dueño su dureza en el trato, instante aprovechado por

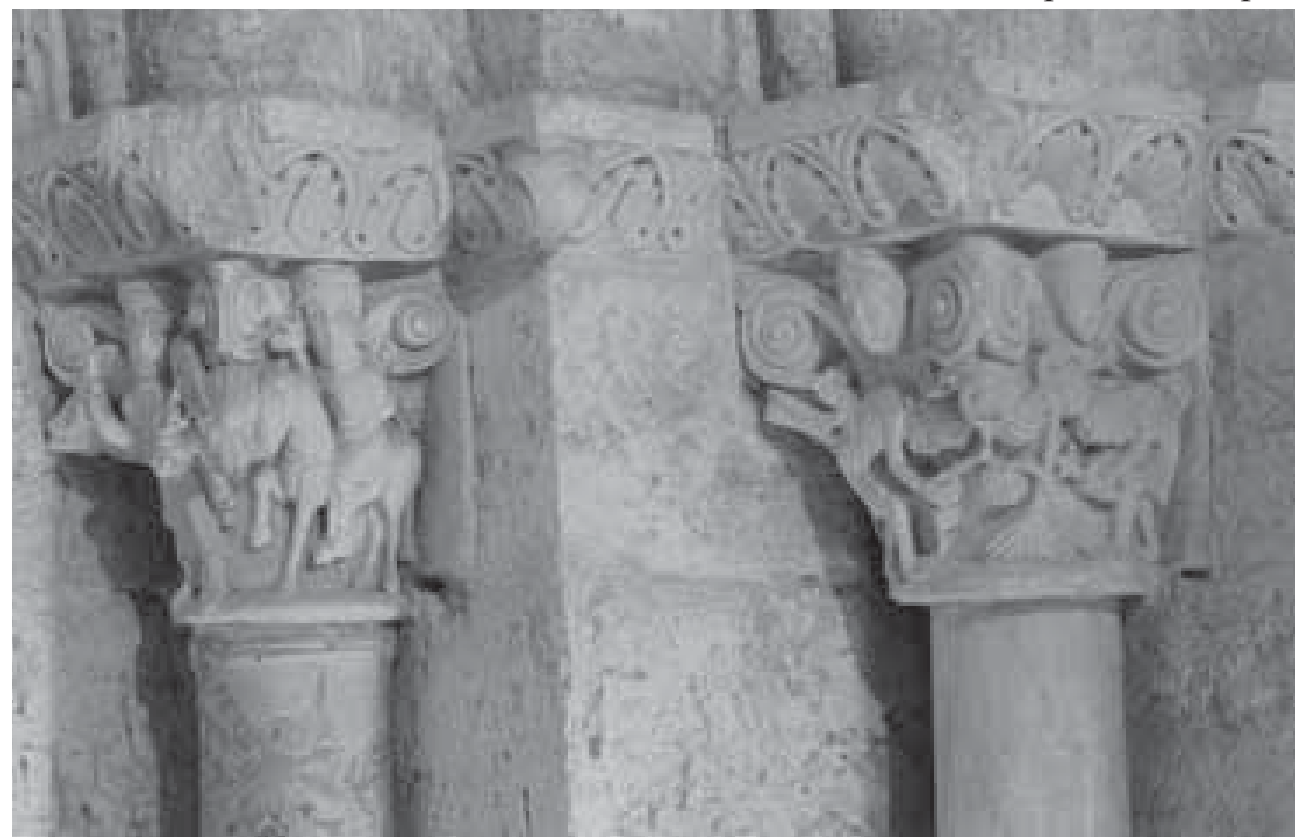

Fig. 3. Carrión de los Condes. Monasterio de San Zoilo. Portada occidental. Capiteles de la jamba derecha. 

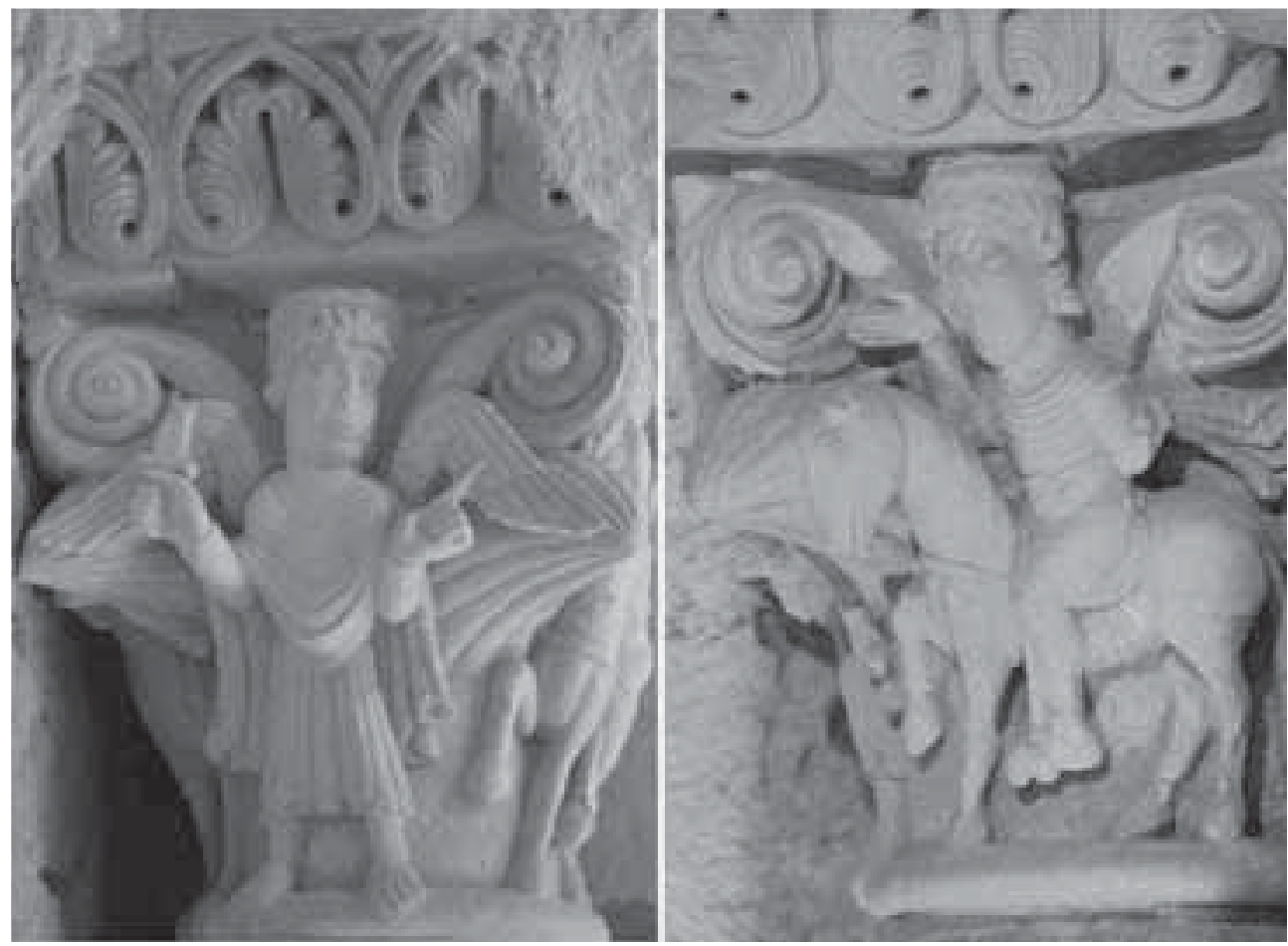

Fig. 4. Carrión de los Condes. Monasterio de San Zoilo. Portada occidental. Jamba derecha. Capitel con la historia de Balaam.

el Ángel para manifestarse al adivino y revelarle la voluntad de Yahvé: que en vez de maldecir a su pueblo lo bendijese.

Serafín Moralejo, al referirse a los ejemplos jaqués e isidoriano, y advirtiendo que en ambos casos el episodio aparecía estrechamente vinculado al del Sacrificio de Isaac, señaló que el tema debía ser interpretado en clave histórica dentro del contexto particular de la Reconquista, momento en el que algunas fuentes de comienzos del siglo XII se refieren a los almorávides con el término de moabitas ${ }^{3}$. No obstante, para Jesús Herrero su finalidad moralizante es clara: ensalzar la humildad

3 S. MoraleJo, "Le origini del programma iconografico dei portali nel Romanico spagnolo", Wiligelmo e Lanfranco nell'Europa romanica, Módena, 1985, pp. 35-51 (especialmente, 38-39). Es posible que el momento y el lugar dotasen a la imagen de un nuevo significado histórico. Pero no debemos olvidar tampoco que la asociación entre el episodio del mago mesopotámico y el sacrificio de Isaac figura ya en el arte paleocristiano como ejemplifica el fresco del denominado cubículo $C$ de las catacumbas romanas de Via Latina (s. IV) analizado por E. Conde Guerri, "Interpretación de la escena de Balaam y su burra (Via Latina B, F y C?) en las fuentes patrísticas y nuevas vinculaciones iconográficas", "Historiam Pictura Refert». Miscellanea in onore di padre Alejandro Recio Veganzones, Città del Vaticano, 1994, pp. 141-174. Sobre las distintas explicaciones a este pasaje veterotestamentario en la patrística antigua como Orígenes, San Ambrosio, Ireneo o Gregorio de Nisa, es válida la recopilación a cargo de M. Minası, "Balaam”, Temi di iconografia paleocristiana (F. Bisconti, coord.), Città del Vaticano, 2000, pp. 132-134. 
ante la presencia de Dios a la vez que ridiculizar cualquier engreimiento personal (Balaam, hombre de ciencia y supuestamente culto, no es capaz de ver lo que sí contempla un sencillo animal famoso por su torpeza) ${ }^{4}$. La lectura no resulta inconveniente si pensamos que se trata de un capitel tallado en el ingreso de una iglesia monástica, habida cuenta que la humildad es una de las virtudes principales que deben practicar los monjes según San Benito.

Incidiendo sobre este aspecto, las fuentes nos revelan cómo el episodio fue uno de los elegidos por los teóricos benedictinos y cistercienses de los siglos XII y XIII para reflejar de modo alegórico algunos de los pilares esenciales de la vida monástica. Así, Hildeberto de Le Mans († 1133) definía a los monjes como "asnos de San Benito" - Vos estis asinus et haedus Benedicti-, explicando que tanto el animal como el jinete son metáfora para el monje que debe llevar siempre al Señor cabalgando sobre él. Mucho más afín con el texto bíblico, su correligionario Julián de Vézelay (1138-1161) utiliza la historia como hilo conductor para explicar el capítulo 58 de la R.B. relativo a la obediencia. Según sus palabras, todo monje debe acatar sin cuestionarse las órdenes de su superior salvo en un caso: cuando estas entren en franca contradicción con la Ley Divina. Entonces, debe hablar alto y declarar que no puede obedecer porque no puede ir contra Dios, sicut asella Balaam, que habló para transmitirle las órdenes dictadas a Yahvé a través del ángel, contrarias a las recibidas por el rey Balak. Por último, obediencia, pero también fortaleza (entendida como cualidad atribuida siempre a este tipo de animales: asinus fortis), son las virtudes que deben revestir al abad de cualquier monasterio según se desprende de los comentarios de Pedro el Venerable (ca. 1136-1137) a Guido de Le Chatel, prior de la Gran Cartuja; de Rainiero de Lieja (1157-ca. 1188) al monje David de su propio monasterio; y del Comentario a la Regla de San Benito escrito por los mismos años en la casa cisterciense de Pontigny tal vez por su propio abad 5 .

Por tanto, esta metáfora de la vita claustralis $^{6}$-dirigida a los cenobitas y no al común de los fieles-, se presenta como más que apropiada para decorar el ingreso de una iglesia prioral recientemente sujeta a la disciplina cluniacense. El principal problema reside en saber si formaba parte de un conjunto iconográfico más amplio, o si, por el contrario,

4 J. Herrero Marcos, Arquitectura y simbolismo del románico palentino, Madrid, 1994, pág. 102.

5 Textos referidos por I.H. Forsyth, "L'Ane parlante: The Ass of Balaam in Burgundian Romanesque Sculpture", Gesta, XX/1 (1981), pp. 59-65. El trabajo se centra en el estudio de otros tres ejemplos de la representación que decoran otros tantos capiteles de las abaciales de Saint-Andoche de Saulieu, Saint-Lazare de Autun y Saint-Georges de La Rochepot. Los tres, ligeramente posteriores a los ejemplos hispanos, refuerzan la idea de una iconografía de corte prioritariamente monástico. No sólo porque todos se emplazan en iglesias de monjes, sino porque en ellos Balaam ha sido figurado con cogulla monacal y, al menos en uno de los casos (Saulieu), porta un evidente báculo en tau propio de los abades (fig. 5).

6 Esa vida comunal que, a ejemplo de los primeros cristianos, con los apóstoles a la cabeza (vita apostolica), debe guiar el discurrir cotidiano de las comunidades monásticas de los tiempos de la reforma gregoriana, tal y como ha puesto de manifiesto G. Constable, "Renewal and Reform in Religious Life. Concepts and Realities", Renaissance and renewal in the twelfth century (R.L. BEnson and G. ConstaBle, eds.), Cambridge, Mass., 1982, pp. 37-67. 

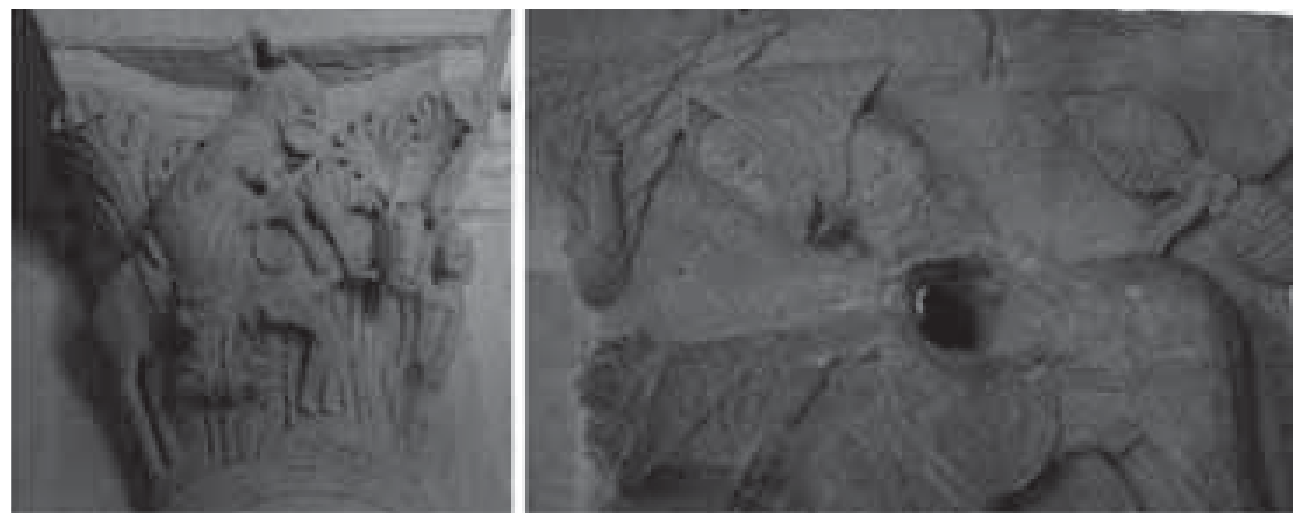

Fig. 5. Saint-Andoche de Saulieu y Saint-Lazare d'Autun.

cada uno de los cuatro capiteles que integraban la portada transmitía un mensaje propio sin relación con los restantes.

Esta correspondencia temática sí parece existir con su compañero en la jamba derecha (fig. 6). En él, cada cara es ocupada por los cuerpos de dos personajes ataviados con faldas cortas que están realizando trabajos agrícolas en una viña. En la parte superior, y en el espacio libre que dejan las enormes volutas que decoran los ángulos del capitel, una gran cara preside cada uno de los frentes. A estos rostros corresponden unas manos que sujetan los tallos de la vid. Con independencia del simbolismo eucarístico que reviste este elemento vegetal, su posición junto a la escena de Balaam sirve de complemento ambiental a la misma al recordar que el suceso acaeció junto a una viña: "Entonces el ángel se puso en una estrechura entre las viñas, entre pared de un lado y pared de otro" (Núm. 22, 24)7.

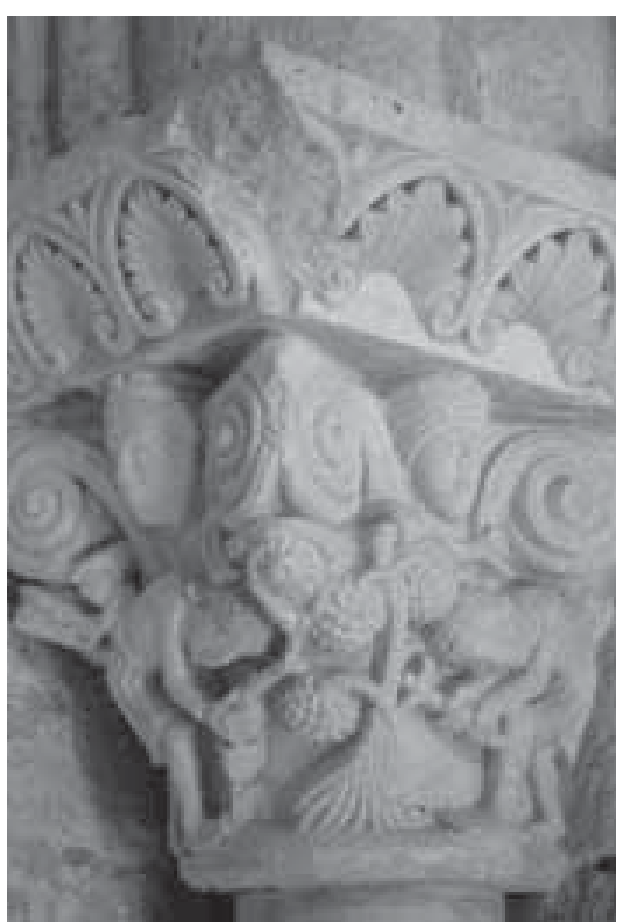

Fig. 6. Carrión de los Condes. Monasterio de San Zoilo. Portada occidental. Jamba derecha. Capitel con escena de vendimia.

7 J. Herrero Marcos, Arquitectura y simbolismo..., op. cit., pp. 102-103. Más complicado nos parece aceptar la interpretación que hace de la escena el mismo autor para quien, presuponiendo que los grandes rostros de la parte superior son una representación de la Divinidad, explica la escultura como el "símbolo claro del dominio de Cristo sobre la eternidad, cuyo origen es la idea de la renovación periódica y eterna del mundo vegetal, firmemente sujeto por las manos del Creador" (Ibíd.). De mayor calado para nuestro estudio es considerar la propuesta de Manuel Castiñeiras, quien analiza las imágenes como una representación de la labor de airear las viñas en primavera, recordando "la vinculación existente entre el entorno de los monaste- 
Mayor dificultad supone establecer una relación semántica similar con los dos capiteles de la jamba izquierda (fig. 7). Dejaremos de lado el más interno, ocupado por sendas parejas de reptiles alados de cola rizada, acompañados por una serpiente tallada en la cara oculta, y que, al margen del significado negativo que se asignó a estos seres y que ha servido a algunos autores para hablar de una alusión a las fuerzas del mal ${ }^{8}$, no creemos que su finalidad fuese más allá de la puramente ornamental.

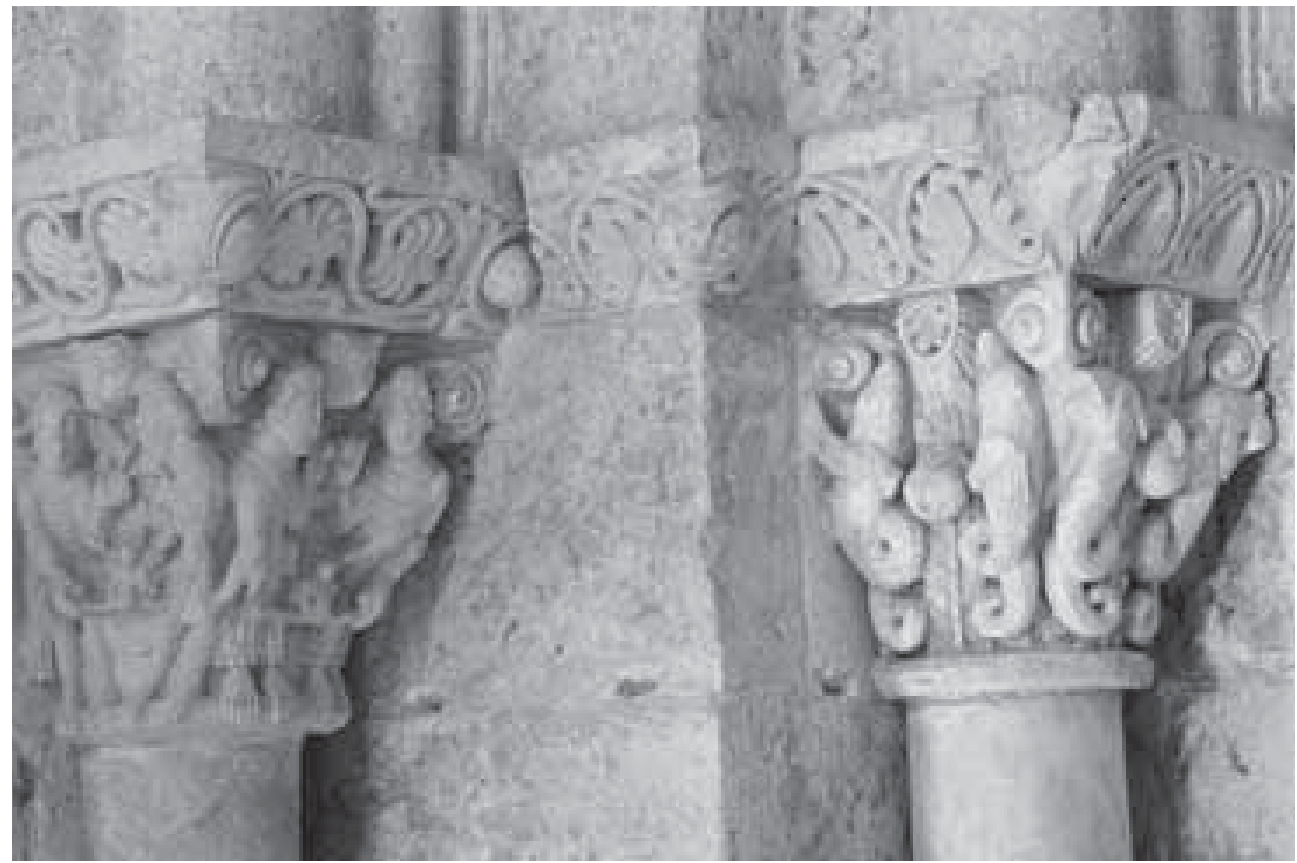

Fig. 7. Carrión de los Condes. Monasterio de San Zoilo. Portada occidental. Capiteles de la jamba izquierda.

El que nos resta presenta la misma imagen duplicada en sus dos caras. Bajo la atenta mirada del rostro de un felino tallado en la parte superior, cuatro personajes masculinos ricamente ataviados con túnicas de bordes orlados con detalles de pedrería y perlas, forman dos parejas, una por cara. Éstos señalan hacia lo alto con una de sus manos mientras que, con la otra, sostienen un paño del que emerge el busto de una pequeña figurilla portando un libro, según esquema compositivo habitual en las representaciones del traslado al Paraíso del alma de un justo por dos ángeles (fig. 8) ${ }^{9}$.

rios benedictinos cluniacenses, de reciente implantación, y la aparición hacia 1100 de la temática del calendario monumental románico en los reinos occidentales peninsulares", como uno de los testimonios del trabajo manual propugnado por la Regla de San Benito: M. CAstiñeiras GonzÁlez, "El Labora: los trabajos y los días en la iconografía románica", Vida y Muerte en el Monasterio Románico (J.Á. GARCíA DE CoRTÁZAR, coord.). Aguilar de Campoo, 2004, pp. 63-83.

8 Así en J. CAStÁn LANASPa, “Una portada románica con capiteles historiados...”, op. cit., pág. 310.

9 Sobre las variantes figurativas del tema adoptadas en el románico L. Herrero Romero, "Notas icono- 

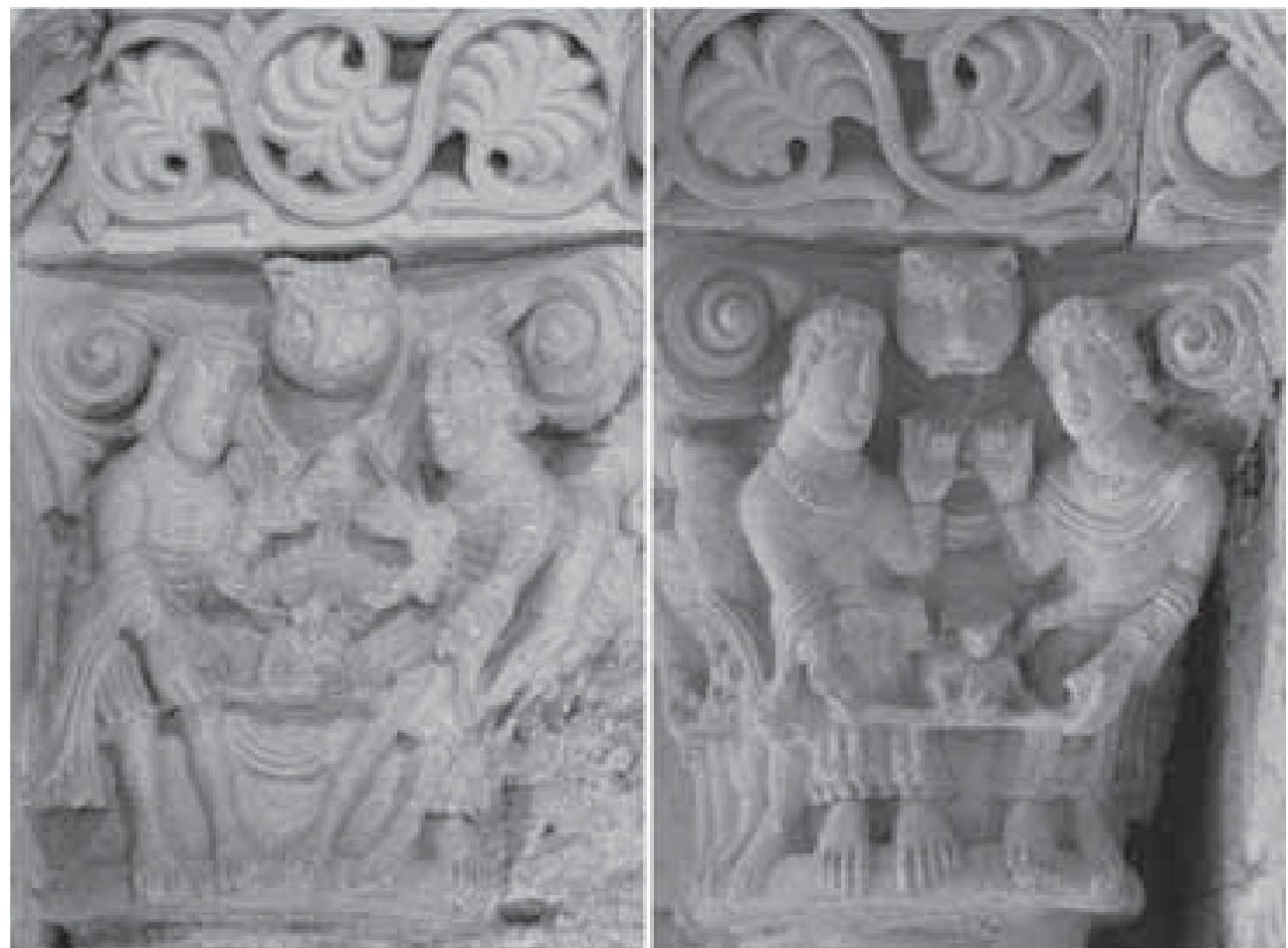

Fig. 8. Carrión de los Condes. Monasterio de San Zoilo. Portada Occidental. Jamba izquierda. Capitel con escena escatológica.

La circunstancia de que el bienaventurado haya sido efigiado únicamente de torso hacia arriba ha llevado a algunos autores a identificarlo con San Juan Bautista ${ }^{10}$, primer titular del monasterio, que murió decapitado por orden de Herodes. Pero, ¿por qué pensar en la imagen del Precursor y no en las de San Zoilo o San Félix, mártires también como él y cuyas reliquias se custodiaban en la iglesia monasterial? ${ }^{11}$. Varios indicios podrían apuntar, ciertamente, a la persona del Bautista. Por una parte, a él

gráficas sobre el tránsito del alma en el románico español”, Estudios de Iconografía Medieval Española (J. YARZA LuACES, ed.). Bellaterra, UAB, 1984, pp. 13-51.

10 J.L. Senra Gabriel y Galán, "La portada occidental...”, op. cit., pp. 61-61, y J. Herrero Marcos, Arquitectura y simbolismo..., op. cit., pp. 100-101.

${ }^{11}$ San Juan Bautista era la advocación de la antigua iglesia, a partir de la que comenzó su andadura el cenobio, y que debió de emplazarse en el lugar ocupado posteriormente por la galilea -más o menos ante el espacio en el que se abre este ingreso-. Será la traslación desde Córdoba de los restos de los mártires hispanorromanos Félix y Zoilo (Zoellus), y su colocación en el altar mayor de la iglesia, lo que propiciará un progresivo cambio en la denominación del centro. Las reliquias fueron conducidas hasta Carrión hacia 1044 -donde, sin embargo, no aparecen citadas hasta 1073- por Fernando, primogénito de los Condes del lugar Gómez Díaz y Teresa, ambos miembros destacados de la familia de los Banu-Gómez, protectores del cenobio durante gran parte del siglo XI al que por esta causa elegirán como sede de su panteón funerario. Sobre el culto a San Zoilo, la veneración de sus reliquias y la vinculación ideológica con los Condes de Carrión, vid. J. Pérez-EmBid WamBa, Hagiología y Sociedad en la España Medieval. Castilla y León (Siglos XI-XIII), Huelva, 2002, pp. 37-39 y 68-71. 
alude una inscripción - de época moderna, todo hay que decirlo- pintada sobre la rosca de una de las arquivoltas del ingreso: ...PILIS CAMELORUM \& ZONAM PELLICEAM... ${ }^{12}$; por otra, circunstancias especiales de su vida permiten establecer una relación simbólica entre él y el personaje de Balaam efigiado en la jamba opuesta. No hay más que avanzar unos cuantos versículos desde el pasaje comentado de la burra para leer que, una vez reconvertido, Balaam precederá en varios siglos a los grandes Profetas en su anuncio del nacimiento del Mesías ${ }^{13}$, al que identifica con la estrella que surgirá de Jacob: "Álzase de Jacob una estrella, surge de Israel un cetro que aplasta los costados de Moab y el cráneo de todos los hijos de Set" (Núm. 24, 17) ${ }^{14}$. Tal vez en este sentido debamos entender el gesto que realiza el adivino con la mano derecha en los cuatro capiteles hispanos conservados: ligeramente levantada y pareciendo señalar hacia el cielo. Aunque en ninguno de ellos se ha incluido la representación del astro sobre su cabeza, puede que con la mano alzada se quisiese hacer alusión al elemento celeste con el que el personaje profetiza la llegada de los tiempos mesiánicos. De este modo quedarían condensados en una única imagen los dos episodios fundamentales narrados por la Biblia que tienen a Balaam como protagonista.

Este advenimiento, anunciado en repetidas ocasiones a lo largo del Antiguo Testamento, tendrá lugar en tiempos del Bautista, precursor de Cristo y última de sus grandes prefiguras quien, coincidentemente, tuvo en la región de Moab uno de los escenarios fundamentales de su predicación. Así, ideológicamente aunados los protagonistas de los dos capiteles historiados de la portada, entre uno y otro representarían como el principio y el fin en toda la serie de personajes bíblicos que profetizaron el triunfo de la Nueva Ley que vendría a sustituir a la mosaica, y en la que se mantendrá el Pueblo de Dios hasta el día del Juicio Final.

Pero, a pesar de todo, nos parece una lectura demasiado rebuscada para una imagen tan estereotipada como es la de la conducción del alma al cielo. Al contrario, creemos que es justamente esto último lo que se quiso representar en Carrión ${ }^{15}$.

12 J.L. Senra ha identificado un pasaje del Evangelio de Mateo en el que se describe la indumentaria del Bautista que reza: "Ipse autem Ioannes habebat vestimentum de pilis camelorum et zonam pelliceam circa lumbos suos” (Mt. 3, 4-5) (cfr. J. L. Senra Gabriel y Galán, “La portada occidental...”, op. cit., pág. 59, nota 7).

13 Y junto a ellos era incluido, cabalgando sobre una borriquilla, en los dramas litúrgicos medievales que se escenificaban en Navidad: L. RÉAU, Iconografía del arte cristiano. Antiguo Testamento, Barcelona, 1996, pág. 257; carácter de profeta mesiánico con origen en las propias epístolas paulinas y en los escritos de San Justino (s. II), destacado igualmente por L. Goosen, "Balaam", De Abdias a Zacarías. Temas del Antiguo Testamento en la religión, las artes plásticas, la literatura, la música y el teatro, Tres Cantos (Madrid), 2006, pp. 56-58.

14 Ya había llamado la atención sobre esta circunstancia Durliat al describir el capitel representando idéntico tema en la portada meridional jaquesa: M. DuRLIAT, La sculpture romane de la route de Saint-Jacques. De Conques à Compostelle, Mont-de-Marsan, 1990, pág. 242. También sobre el carácter profético y redencional del Balaam carrionés: J.L. HERNANDo GARRIDO, "La escultura románica en Palencia: un balance historiográfico", Palencia en los siglos del románico, Aguilar de Campoo, 2002, pp. 9-35 (especialmente pp. 15-16 y nota 31).

15 Para J. CASTÁn LANASPA, “Una portada románica con capiteles historiados...”, op. cit., pág. 310, que así lo ha entendido, la cabeza de león de la parte alta es símbolo de Dios mismo efigiado como el León de Judá al que se refiere el Apocalipsis. En este contexto, los personajes de mayor tamaño, pese a carecer de alas, son sin duda ángeles que indican su cercanía a la Divinidad a través de la riqueza de sus vestiduras. También para 
No está de más recordar que, ante esta puerta, las fuentes hablan de la existencia de una galilea, en cuyo ámbito inferior -el dispuesto al mismo nivel que el ingreso-, se encontrarían sepultados los Condes de Carrión, benefactores del monasterio ${ }^{16}$. Por ello, nada mejor que un tema de significación funeraria, que evoca la esperanza en la salvación del alma y su ingreso en el Reino de los Cielos, para decorar un capitel abocado a un espacio de funcionalidad igualmente sepulcral: el panteón de los señores de la villa.

Sea como fuere, la complejidad del programa iconográfico, que sobrepasaba con creces los limitados conocimientos sobre Historia Sagrada de la mayoría de los fieles del momento, parece así prioritariamente -por no decir exclusivamente- dirigido a aquéllos que habitaban entre los muros de la clausura carrionesa, a sus monjes: si en la jamba derecha las imágenes les exhortaban hacia la humildad, la obediencia y a la fortaleza necesarias para la vida monástica, en la izquierda les recordaban su obligación perpetua de orar por la salvación del alma de los nobles que habían sido sus protectores.

Lamentablemente, no conocemos cuál sería la decoración de los capiteles de la desaparecida portada norte del edificio, un ingreso que seguiría en su configuración el modelo de puerta coronada con friso corrido como el que se trabajó en fechas parejas en el castillo oscense de Loarre y que sería el precedente de los posteriores de Santa María y Santiago en la propia villa de Carrión ${ }^{17}$. Tal vez, y esto entra dentro del campo de la especulación (aunque especulación posible), los siguientes ejemplos arrojen algo de luz sobre el particular.

\section{De un modelo de vida al exemplum monachorum: el binomio lujuria y avaricia en Dueñas y Frómista, como testimonio de una constante vinculada a Cluny}

En el segundo cuarto del siglo X, Odón, segundo abad de Cluny (927-942), arremetía contra las costumbres licenciosas de los obispos de su tiempo -a los que

M. A. García Guinea, Románico en Palencia: guía, Palencia, 1998, el tema "pudiera representar la salvación de un alma" (pág. 288).

16 Sobre los datos conocidos de esta estructura, así como una reconstrucción hipotética de su espacio, además de lo señalado por el autor en este mismo volumen, vid. los trabajos de J.L. SenRA GABRIEL y GaLÁN, "Aproximación a los espacios litúrgico-funerarios en Castilla y León: pórticos y galileas", Gesta, XXXVI/2 (1997), pp. 122-144, ID., "Les massifs occidentaux des églises dans les royaumes du nord-ouest de la Péninsule Ibérique", Avant-nefs \& espaces d'accueil dans l'église entre les IVe et le XII siècle. Actes du colloque international du CNRS (Auxerre, 17-20 juin 1999), París, 2002, 15 pp. (manejada separata sin paginar), e ID., "En torno a las estructuras occidentales de las iglesias románicas: formulación arquitectónica y funcional de las galileas (ca. 1030-1150)", Espacios y estructuras singulares del edificio románico (P. L. HUERTA, coord.), Aguilar de Campoo, 2008, pp. 121-155.

${ }_{17}$ Así lo viene defendiendo desde hace unos años J.L. SENRA Gabriel y Galán, "Nuevos hallazgos románicos en el Monasterio de San Zoilo de Carrión de los Condes (Palencia)", Archivo Español de Arte, nº 293 (2001), pp. 88-95, donde el propio autor anuncia un mayor desarrollo del planteamiento en ID., "La sculpture des royaumes chrétiens du Nord-Ouest de la Péninsule Ibérique vers l'an 1100: la captation d'un modèle de portail monumental", Colloque International à l'occasion du gème centenaire du cloître de Moissac (Moissac, 28-30 juin, 2000). 
describe sometidos a los pecados más abominables y a los placeres de la carne-, refiriéndose a ellos en los siguientes términos:

(...) los ministros de la Iglesia se hartan de carne, están ebrios de orgullo, resecos de avaricia, debilitados por la voluptuosidad, atormentados por la maldad, abrasados de ira, divididos por la discordia, muertos de envidia y aplastados por la lujuria ${ }^{18}$

Parece como si de sus palabras se pudiera deducir que tales vicios sólo afectasen al orden episcopal y al clero seglar, estando libres de toda sospecha, por tanto, los monjes. Nada más alejado de la realidad. ¿Qué otro sentido tendría si no la miniatura del Infierno silense?

La inquietante representación -de página entera-, es un fragmento de un suntuoso antifonario que se cosió, en fecha indeterminada -pero anterior al s. XIX-, al Beato que se terminaba de iluminar hacia 1109 en el escritorio del monasterio de Santo Domingo de Silos, encargado algunas décadas antes por el entonces abad Fortunio. En ella, San Miguel, balanza en mano, se sitúa en el exterior de un tetralóbulo que contiene las figuras de cuatro diablos disformes -cuyos nombres son reseñados en rótulos adjuntos: BeElzebub, Atimos, RadAmas y BARRABAS-, que se disponen a atormentar con grandes garfios a otros tres personajes que han sido condenados: una pareja de amantes abrazados en el lecho, más un tercero que centra la composición, de cuyo cuello pende una pesada bolsa y al que atacan, además, parejas de sapos y serpientes. Encima de éste, la leyenda no puede ser más clara sobre su identidad: Dives ${ }^{19}$. Ciertamente, ninguno de los tres aparece tonsurado ni ataviado con hábito. Sin embargo, la pertenencia de la página a un libro creado en el monasterio y cuyo destino era el de ser usado exclusivamente por la comunidad, no deja lugar a duda sobre a quiénes iba dirigida la advertencia: directamente a los cenobitas que habitaban -y habitarían en el futuro- la clausura silense. Si realmente éstos se mantenían al margen de lujuria y avaricia, una admonición tan explícita no habría tenido demasiado sentido.

18 Cfr. A. Del Olmo García., Iconografía sexual en el románico, Salamanca, 1999, pág. 81.

19 Sobre esta interesante página, son ya clásicos dos trabajos que vieron la luz de forma coincidente. En el primero se trataba de explicar su extraña iconografía en función de antiguas fuentes gnósticas: M. SCHAPIRO, "From Mozarabic to Romanesque in Silos", The Art Bulletin, XXI (1939), pp. 312-374. (Trad. castellana "Del mozárabe al románico en Silos", Estudios sobre el románico, Madrid, 1984, pp. 37-119). En el segundo, lo mismo era explicado a partir de la escatología musulmana: M. CHURRUCA, Influjo oriental en los temas iconográficos de la miniatura española. Siglos X al XII. Madrid, 1939, pp. 36-42. Una revisión de ambos, con la incorporación de un estudio sobre la geometría interna del diseño en relación con el número áureo en J. YARZA LuACES, "El Infierno del Beato de Silos", Estudios Pro Arte, no 12 (1977), pp. 26-39 (manejada la reed. en Formas artísticas de lo imaginario, Barcelona, 1987, pp. 94-118); siendo también la obra el punto de partida de otro trabajo del mismo autor: ID., "San Miguel y la balanza. Notas iconográficas acerca de la psicostasis y el pesaje de las acciones morales”, Boletín del Museo e Instituto "Camón Aznar», VI-VII (1981), pp. 5-36; y citada de modo recurrente en ID., "La présence du diable dans l'art roman espagnol: forme, déguisement, role", Démons et merveilles au Moyen Age. Actes du IV Colloque International (Nice, 1987), Niza, 1990, pp. 195-241. 
Y lo tenía. Porque en efecto, y aunque separados por casi siglo y medio, ambos testimonios deben todavía ponerse en relación con un tercer dato. Entre las faltas más duramente perseguidas tanto por los reformadores papales como por los cluniacenses de fines de la undécima centuria y principios de la siguiente, destacan dos especialmente penadas: la simonía y el nicolaísmo. La primera refería la práctica de la compraventa de oficios eclesiásticos en aras de un beneficio económico; el segundo, la inobservancia de la castidad y del celibato, algo que en el caso del clero seglar era todavía más grave, si cabe, dado que la posibilidad de tener descendencia solía desembocar en la sucesión pactada de padres a hijos en los cargos eclesiásticos -con la consiguiente fragmentación del patrimonio-- En el fondo, nuevamente, avaricia y lujuria ${ }^{20}$.

Para el caso particular hispano, la preocupación se hace patente antes aún de la adopción de la Reforma Gregoriana, como delatan numerosas disposiciones conciliares promulgadas durante el reinado de Fernando I, y cuya reiteración no es sino una prueba más de que tanto un pecado como el otro debían estar a la orden del día entre los hombres de Iglesia ${ }^{21}$.

Así, en Coyanza (1055), se prohíbe a los clérigos que vivan en su casa con mujeres, a excepción de la madre, la hermana, la tía o la nodriza; quienes, a su vez, estarán obligadas a vestir de negro o, en su defecto, de un solo color tanto el cuerpo como la cabeza ${ }^{22}$. Por lo que se refiere a los monjes, ordena que se sometan bien a la regla de San Benito, bien a la de San Isidoro ${ }^{23}$, ha-

20 La ligereza de costumbres del clero es tema frecuente en uno de los testimonios literarios medievales más interesantes que han llegado hasta nuestras manos: la denominada Poesía de los Goliardos (ss. XII-XIII). Entre sus versos no faltan alusiones a la compraventa de objetos religiosos y a la inobservancia de la castidad por parte de monjes y sacerdotes, como refleja el siguiente de GUALTERIO DE CHATILLÓN, inequívocamente titulado Contra la simonía: “¿Llorad, hijas de Sión! Los jefes de la Iglesia andan hoy lejos de imitar a Cristo. / Si un sacerdote o un diácono de pocos haberes quiere conseguir lo que ambiciona, sólo debe seguir el camino conocido: guíese por las artes de Simón el Mago y, como otro Guejazi, se le dará lo que quiere. / El orden eclesiástico está más postrado que el de los laicos: la Esposa de Cristo se pone a la venta; la que antes sobresalía está ahora a merced de todos: se venden los altares, se vende la Eucaristía, a pesar de que nada valen las dignidades compradas (...) Y para decir de una vez lo más desagradable: / el mismo Crisma se pone en venta: los corazones de los viejos se llenan de lujuria sin que nadie trate de atajarla. / Los viejos y decrépitos sorben el veneno del néctar prohibido como si fueren adolescentes. / Y así nadie vive castamente; el muro de la castidad se ha desmoronado..." (Cfr. R. Arias y Arias, La Poesía de los Goliardos, Madrid, 1970, pág. 81-83, y recogidos por I. Ruiz MonTEJo, "La temática obscena en la iconografía del románico rural”, Goya, no 147 (1978), pp. 136-146 (pág. 140) y E. Mitre, Iglesia y vida religiosa en la Edad Media, Madrid, 1991, pp. 139-140).

21 Faltas a las que se sumaban la inobservancia de las reglas referentes al vestido, a la tonsura, a la prohibición de llevar armas y la ignorancia general del clero. Para una visión de conjunto: A. SÁnchez CANDEIRA, Castilla y León en el siglo XI. Estudio del reinado de Fernando I, Madrid, 1999, pp. 196 y ss.

${ }^{22}$ Mulieres secum extraneas in domo non habeant, nisi tantum matrem aut amitan, sororem aut materteram, aut mulierem probatam, et omnes indutas nigra veste, tam in corpore quam in capite, et dent fideiussores ut nec per esa ullum adulterium fiat: Concilio de Coyanza (1055), III-15 (cfr. A. GArcía Gallo, El Concilio de Coyanza. Contribución al estudio del Derecho canónico español en la Alta Edad Media, Madrid, 1951, pág. 22).

23 Deinde statuimus ut omnia monasteria nostra secundum possibilitates suas adimpleant ordinem sancti Isidori vel sancti Benedicti: Concilio de Coyanza (1055), II-1 (cfr. ibíd., pág. 18). 
biendo ya legislando ambas con anterioridad respecto a la conducta sexual de los cenobitas ${ }^{24}$.

La fórmula se repite, sin apenas variación, una década más tarde en Compostela (1063). Allí no sólo es a obispos y sacerdotes, sino también a los religiosos, a los que se hace extensiva la norma expresa de no cohabitar con mujeres extrañas que no sean la hermana, la madre o el ama ${ }^{25}$. En el mismo concilio, otra disposición declaraba como simoníacos y no verdaderos cristianos, a los obispos, presbíteros, diáconos, y demás eclesiásticos que traficaran con cargos, sacramentos o bendiciones ${ }^{26}$.

Por ello, no es extraño que la plasmación de estos vicios se convierta en tema habitual en la escultura románica (dado el papel jugado siempre por el arte como uno de los canales privilegiados de transmisión de preceptos), apareciendo am-

24 San Isidoro incluye entre las faltas más graves que puede cometer un monje tanto el trato familiar con mujeres -feminarum familiaris-, como acostarse con otro en el mismo lecho -cum altero in uno lecto iacuerit-. Ambas están penadas con azotes y sanción que será determinada por el abad, además de con excomunión duradera: Regula Isidori, cap. XVII "De delictis" (cfr. J. CAMPos RuIZ e I. Roca Melia, Santos Padres Españoles. II. San Leandro, San Isidoro. San Fructuoso. Reglas monásticas de la España visigoda. Los tres libros de las «Sentencias», Madrid, 1971, pp. 114-116). Por lo que a San Benito se refiere, aconseja la oración para luchar contra los deseos de la carne, causa de muerte espiritual: In desideriis vero carnis ita nobis Deum credamus semper esse praesentem cum dicit Propheta Domino: "Ante te est omne desiderium meum». Cavendum ergo ideo malum desiderium, quia mors secus introitum delectationis posita est. Unde Scriptura praecipit dicens: "Post concupiscentias tuas non eas»: Regula Benedicti, cap. VII, 23-25, "De humilitate" (Regla de San Benito, ed. de G. M. Colombás e I. Aranguren, Madrid, 1979, pág. 93); a la vez que conmina al monje a amar la castidad -castitatem amare-: RB, IV, 64 (ibid., pág. 85). Realmente, la concupiscencia -y no sólo con mujeres, sino la sodomía entre los mismos monjes--, debió ser algo que preocupó notablemente a ambos dado que en los dos tratados se dedica un capítulo completo a legislar sobre el dormitorio y los lechos (RI, XIII "De stramentis"; RB, XXII "Quomodo dormiant monachi”). Así se prescribe que, en la medida de lo posible, el dormitorio sea único para toda la comunidad, que permanezca una luz encendida durante toda la noche, y que los hermanos más jóvenes no tengan jamás sus camas juntas, sino separadas con las de otros más ancianos y de virtud probada. Pasando al campo de las artes plásticas, en este mismo sentido se ha interpretado la temática de un capitel de Vézelay en el que se representa el rapto de Ganímedes por Zeus. Lejos de ser un mero ejercicio de erudición clásica, debió ser tallado como advertencia contra una práctica al parecer muy extendida dentro de los muros del monasterio. Sobre el particular vid.: J. ADHÉmAR, "L'enlevèment de Ganymède sur un chapiteau de Vézelay”, Bulletin Monumental, XCI (1932), pp. 290-292, e ID., Influences antiques dans l'art du Moyen Age français. Recherches sur les sources et les thèmes d'inspiration, Londres, 1939, pp. 222-223; I. H. Forsyth, "The Ganymede Capital at Vézelay”, Gesta, XV (1976), pp. 241-246; J. YARZA LuACES, "Sobre la función de la escultura románica figurativa”, Cimal, no 7 (1980), pp. 19-23 (pág. 20); y, más recientemente, lo ha recordado de nuevo J.L. Hernando Garrido, "Los grandes talleres escultóricos en los monasterios románicos castellano-leoneses", Los monasterios medievales, Aguilar de Campoo, 2001, pp. 45-71, (pp. 49-50). Esta atribución había sido cuestionada, no obstante, por W. WeIsBACH, Reforma religiosa $y$ arte medieval, Madrid, 1949, pp. 154 y ss.

25 Mulieris vero extraneae nullam communionem, neque consortium cum Episcopis, nec cum Monachis habeant; nec ad habitandum permittimus; propter necessitatem enim, matrem, amitam, vel sororem, morem, et habitum religiosum habentes, non vetamus: Concilio Compostelano (1063), III-2 (cfr. G. MARTínez DíEz, "El Concilio Compostelano del reinado de Fernando I", Anuario de Estudios Medievales, I (1964), pp. 121138, esp. pág. 129).

${ }^{26}$ Et nullus praesumat simoniacus esse quaerens sibi ipsam ordinationem; nec Episcopus nec Presbyter, nec Diaconus, nec omnibus ministris Ecclesiae emere, nec vendere, nic ipsa sacra ministeria, nec oleum, nec ulla de ordine Ecclesiastico. Quod qui fecerit simoniacum se esse cognoscat, non verissimum Christianum: Concilio Compostelano (1063), II-3 (cfr. ibíd., pág. 128). 
bos temas normalmente asociados. Por lo mismo, tampoco debe ser casual que sus manifestaciones más tempranas en nuestra zona de estudio sean prácticamente contemporáneas a la sustitución del antiguo rito hispánico por el romano, y a la implantación de las primeras comunidades cluniacenses, en cuyos centros, coincidentemente, encontramos los que tal vez sean sus primeros ejemplos.

Así lo prueban sendos capiteles en las portadas septentrional de San Martín de Frómista y occidental de San Isidro de Dueñas.

El 29 de diciembre de 1073, fecha simbólica del aniversario del óbito de Fernando I, y en compensación del pago anual que el citado monarca había establecido con la poderosa abadía de Cluny y que se había visto interrumpido tras su muerte, su sucesor Alfonso VI hace entrega a la casa borgoñona del monasterio de Dueñas, antiguo cenobio cuyos orígenes (como fundación femenina de la que toma el apelativo), tal vez puedan remontarse a la época visigoda. Al igual que sucedió con el priorato de San Zoilo de Carrión, poco es lo que podemos conocer del templo plenorrománico que se levantaría en estas décadas finales del siglo XI. Remodelado y ampliado durante el tardorrománico, fue prácticamente destruido por un incendio en el XVI. A su etapa más antigua debe corresponder la fachada occidental, flanqueada por dos torres cilíndricas en los extremos y en la que se abre la puerta de ingreso (fig. 9), con pareja de columnas acodilladas por jamba, rematadas por sendos capiteles labrados (fig. 10).

El único figurado es el más próximo al umbral por el costado derecho (fig. 11). La cara interna está ocupada por la figura sedente del avaro que sujeta con las manos las correas de la bolsa que le pende del cuello ${ }^{27}$, en tanto que un personaje desnudo y de rostro grotesco, ubicado a su derecha, parece querer rodearle el hombro con uno de sus brazos ${ }^{28}$. En el lado externo y mucho más dañada, la representación clásica de

27 El gesto fue erróneamente interpretado por Antón como la intención del personaje de abrir sus ropas para mostrar su desnudez, buscando de este modo el paralelismo temático con la imagen de la cara contigua: F. Antón, "San Isidoro de Dueñas”, Archivo Español de Arte, no 98 (1952), pp. 129-142 (pág. 132).

28 La bolsa al cuello, que pende y pesa hasta llegar a ahogar a su dueño, es el atributo distintivo de las representaciones románicas del avaro desde sus primeros momentos. Así había sido ya imaginado por Prudencio en su Psicomaquia (ca. 398-400) cuando, al describir el enfrentamiento entre Avaricia y Caridad, dice de la primera que "alzando su vestido para formar una ancha bolsa, agarró con su corva mano cuantos objetos preciosos abandonó el Lujo voraz... No le basta el haber llenado los amplios pliegues; le place el apretar en bolsas esa torpe ganancia y ensanchar con sus rapiñas los repletos talegos...": Aurelio Prudencio, Psychomachia (en Obras Completas, ed. A. Ortega e I. Rodríguez, Madrid, 1981, pp. 305-361, esp. pág. 337). El iconograma básico puede verse enriquecido con la adición de uno o varios diablos, sin que su presencia o ausencia varíe el significado general del tema. Sobre el particular, sigue siendo punto de referencia el trabajo de J. MARTINBAGNAUDEZ, "Les représentations romanes de l'avare. Etude iconographique", Revue d'histoire de la spiritualité, 50 (1974), pp. 397-432. Algo más tardía, pero siempre dentro de la plástica románica, comienza a ser habitual la identificación -o cuando menos asociación-, de la figura del avaro con Judas, en lo que supone una extensión de la condena no sólo a los avaros, sino a usureros, mercaderes y a todos aquellos que se enriquecen con la especulación y el fraude, como ha estudiado B. MARIÑo, "Iudas Mercator Pessimus. Mercaderes y peregrinos en la imaginería medieval", Los caminos y el arte. Actas del VI Congreso Español de Historia del Arte (Santiago de Compostela, 16-20 de junio, 1986), Santiago de Compostela, 1989, vol. III, pp. 31-43. Siguiendo en la evolución del tema iconográfico, un catálogo completo de los castigos infernales que esperan a éstos fue tallado en un ejemplo ya de fines del período como es la portada occidental de la colegiata de Tudela, tratada por ID., 
la lujuria vista como una mujer desnuda sufriendo el castigo de los reptiles (femme aux serpens). Aunque es difícil de precisar, parece que los bultos que quedan a su izquierda son los restos de otra figurilla también desnuda e igualmente demoníaca, estableciéndose así un paralelo compositivo con la representación de la cara contraria ${ }^{29}$.

"Sicut in terra et in inferno: la portada del juicio en Santa María de Tudela", Archivo Español de Arte, n' 246 (1989), pp. 157-168, en el que alude a la tradición cristiana como origen de los diferentes suplicios, y por $\mathrm{M}^{\mathrm{a}}$ L. Melero Moneo, "Los textos musulmanes y la Puerta del Juicio de Tudela (Navarra)", Actas del V Congreso Español de Historia del Arte (Barcelona, 29 de octubre - 3 de noviembre, 1984), Barcelona, 1987, pp. 203-215, interpretados como dependientes de la escatología islámica. Junto al infierno navarro, también es paradigmático en este sentido el figurado en la obra mateana de la portada occidental compostelana: B. MARIÑo, "El Infierno del Pórtico de la Gloria", Actas del Simposio Internacional sobre "O Pórtico da Gloria e a Arte do seu Tempo», (Santiago de Compostela, 3-8 de outubro, 1988), Santiago de Compostela, 1991, pp. 383-397. Una visión de conjunto en la que se analiza el panorama sociocultural y religioso que amparó el nacimiento de estas representaciones, así como un completo repertorio de las mismas en la plástica peninsular, rigurosamente descrito y dibujado, en A. Gómez Gómez., El Protagonismo de los otros. La imagen de los marginados en el Arte Románico, Bilbao, 1997, pp. 23-53, a cuya bibliografía remitimos.

29 Las antiguas representaciones de la $\Gamma \alpha \iota \alpha$ de los griegos, o de la Tellus romana, (deidades ctónicas, símbolo de la fecundidad de la tierra), como mujeres jóvenes cuyos senos parcialmente desnudos amamantaban a niños y, en ocasiones, incluso, a algún animal entre los que se podían contar los sapos o las serpientes, derivaron durante el románico en la imagen plástica del castigo de la lujuria. Para ello no había sino que interpretar bajo la óptica cristiana los componentes del antiguo iconograma clásico: la serpiente, animal maléfico y de connotaciones negativas por excelencia, asediando a una mujer desnuda, sensualidad perseguida hasta límites insospechados por la Iglesia medieval. Junto a ello, los vínculos ideológicos que se podían establecer con la caída en el Paraíso y por tanto con el origen de la presencia del pecado en el mundo: Eva, mujer y desnuda, tentada por una serpiente. La migración simbólica, apuntada ya por J. ADHEMAR, Influences antiques..., op. cit., pp. 197-200, fue ampliamente desarrollada con posterioridad por J. LECLERCQ-KADANER, "De la Terre-Mère à la Luxure. A propos de "La migration des symboles»", Cahiers de Civilisation Médiévale, n 69 (1975), pp. 37-43. En él se basan investigaciones posteriores sobre el tema entre las que recogemos las de A. WEIR y J. JERMAN, "La femme aux serpents, l'homme aux serpents and l'avare", Images of Lust. Sexual Carvings on Medieval Churches, Londres/Nueva York, 1986, (Reed. Londres/Nueva York, 1999), pp. 58-79, y, en castellano, Mª del P. Carrillo Lista y J. R. Ferrín GonzÁlez, "La figura de la mujer con serpientes y el castigo de la lujuria en el arte románico", La Vida Cotidiana en la España Medieval. Actas del VI Curso de Cultura Medieval (Aguilar de Campoo, 26-30 septiembre, 1994), Madrid, 1998, pp. 389-408 ; P. RoDríGUEz BARrAL, "Reflexiones sobre el castigo de la avaricia y la lujuria a propósito de su representación en la escultura románica catalano-aragonesa", Codex Aqvilarensis, no 21 (2005), pp. 6-28; y P. L. Huerta HuerTA, "Las visiones infernales: pecados, pecadores y tormentos", Poder y seducción de la imagen románica, Aguilar de Campoo, 2006, pp. 79-116 (esp. 93-97). De mayor trascendencia para nuestro trabajo, por lo que volveremos a él en breve, es el de V. NoDAR, "De la Tierra Madre a la Lujuria, a propósito de un capitel de la girola de la Catedral de Santiago", Profano y pagano en el arte gallego, Santiago de Compostela, 2003, pp. 335-347. Buena recopilación de los principales ejemplos franceses por J. SAugnieux, "Culture religieuse et culture profane. Les représentations de la luxure dans l'art francais du XII" siècle”, Cultures populaires et cultures savantes en Espagne du Moyen Age aux Lumières, París, 1982, pp. 80-91; mientras que para los hispanos, y como en el caso de la avaricia, catálogo, descripción y dibujos en A. Gómez Gómez, El Protagonismo..., op. cit., pp. 55-71, a cuyo repertorio bibliográfico remitimos nuevamente. En todos ellos, textos ilustrativos de castigos infernales en los que podía encontrar justificación la imagen, como el denominado Apocalipsis de Pablo, apócrifo del siglo IV, en el que los que han atentado contra la castidad son mordidos por gusanos y serpientes: Et vidit in alio loco viros ac mulieres, et vermes et serpentes comedentes eos (cfr. A. WeIr y J. Jerman, Images of Lust..., op. cit., pág. 58); o la Visión de San Alberico (después de 1109), en la que este suplicio se reserva tanto a las adúlteras como a las madres que se han negado a amamantar a sus hijos o a aquéllos otros que han quedado huérfanos. (Reseñado tanto por J. AdHEMAR, Influences antiques..., op. cit., pág. 198, nota 2, como por J. LeClercQ-Kadaner, “De la Terre-Mère...”, op. cit., pág. 41, nota 46, y A. GómeZ Gómez, El Protagonismo..., op. cit., pág. 57). 


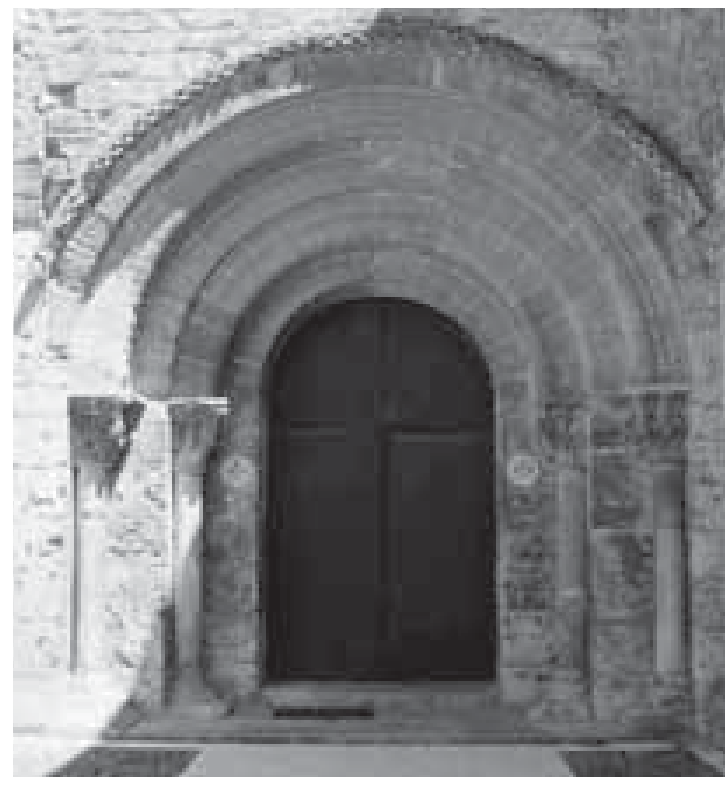

Fig. 9. Dueñas. Monasterio de San Isidro. Portada occidental.

En Frómista la representación del binomio es dúplice ${ }^{30}$. La primera, alejándonos por un momento del ámbito estrictamente liminar (aunque visual y topográficamente asociado a él), se desarrolla sobre un capitel de la nave del Evangelio, frontero al ingreso norte ${ }^{31}$. En la cara mayor de la cesta, una figura masculina, barbada, y que simula estar sentada, sujeta fuertemente con sus manos las largas correas de una bolsa que le pende del cuello. Está flanqueado por dos seres demoníacos, alados y desnudos, que dirigen sus manos hacia la cabeza del pecador; parte de su cuerpo que, por otra parte, parece que está co-

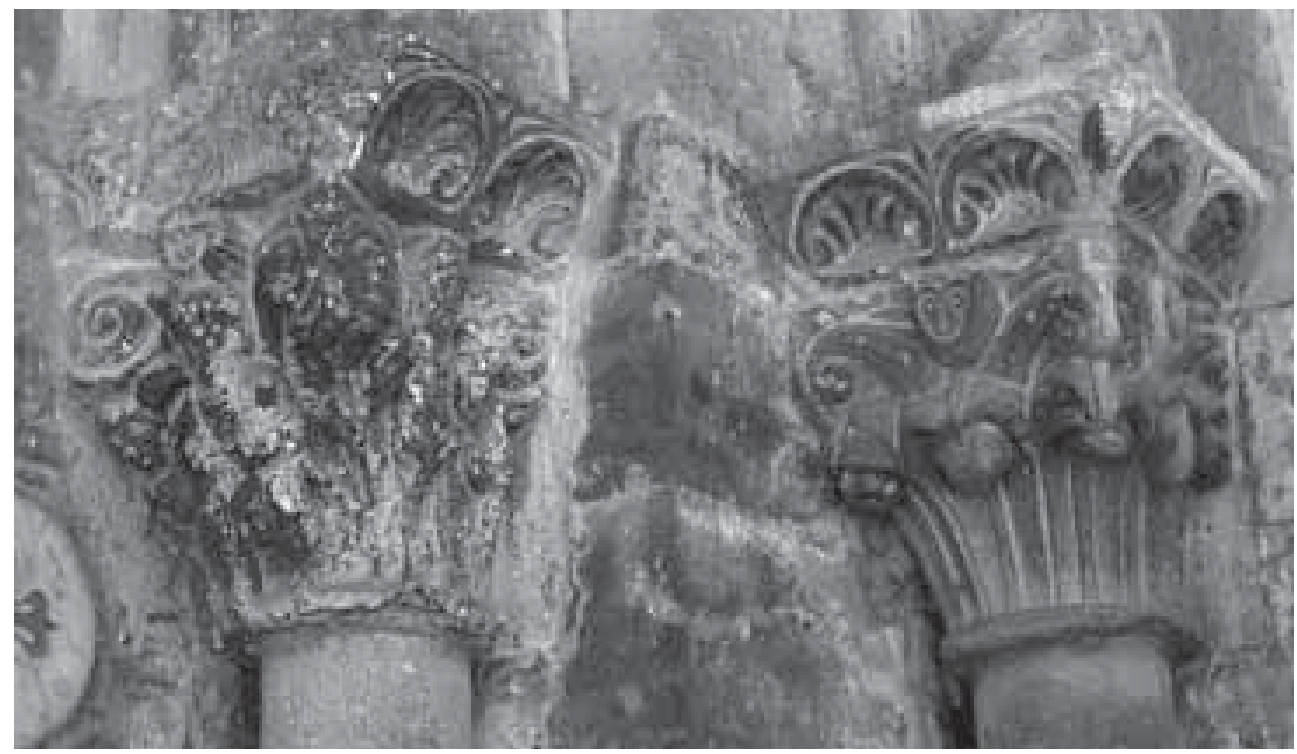

Fig. 10. Dueñas. Monasterio de San Isidro. Portada Occidental. Capiteles de la jamba derecha.

${ }^{30}$ Representaciones que fueron definidas por Torres Balbás como "las más antiguas que del desnudo nos ha dejado el arte románico en España": L. TORRES BALBÁs., "Notas sobre la escultura románica española", Arquitectura, $\mathrm{n}^{\circ} 9$ (1919), pp. 97-102 ( pp. 100-101).

${ }^{31}$ Pieza sobre la que incidió especialmente S. Moralejo, "Cluny y los orígenes del románico palentino: el contexto de San Martín de Frómista", Jornadas sobre el arte de las Órdenes Religiosas en Palencia (Palencia, 1989), Palencia, 1990, pp. 7-33 (esp. 22-24). 

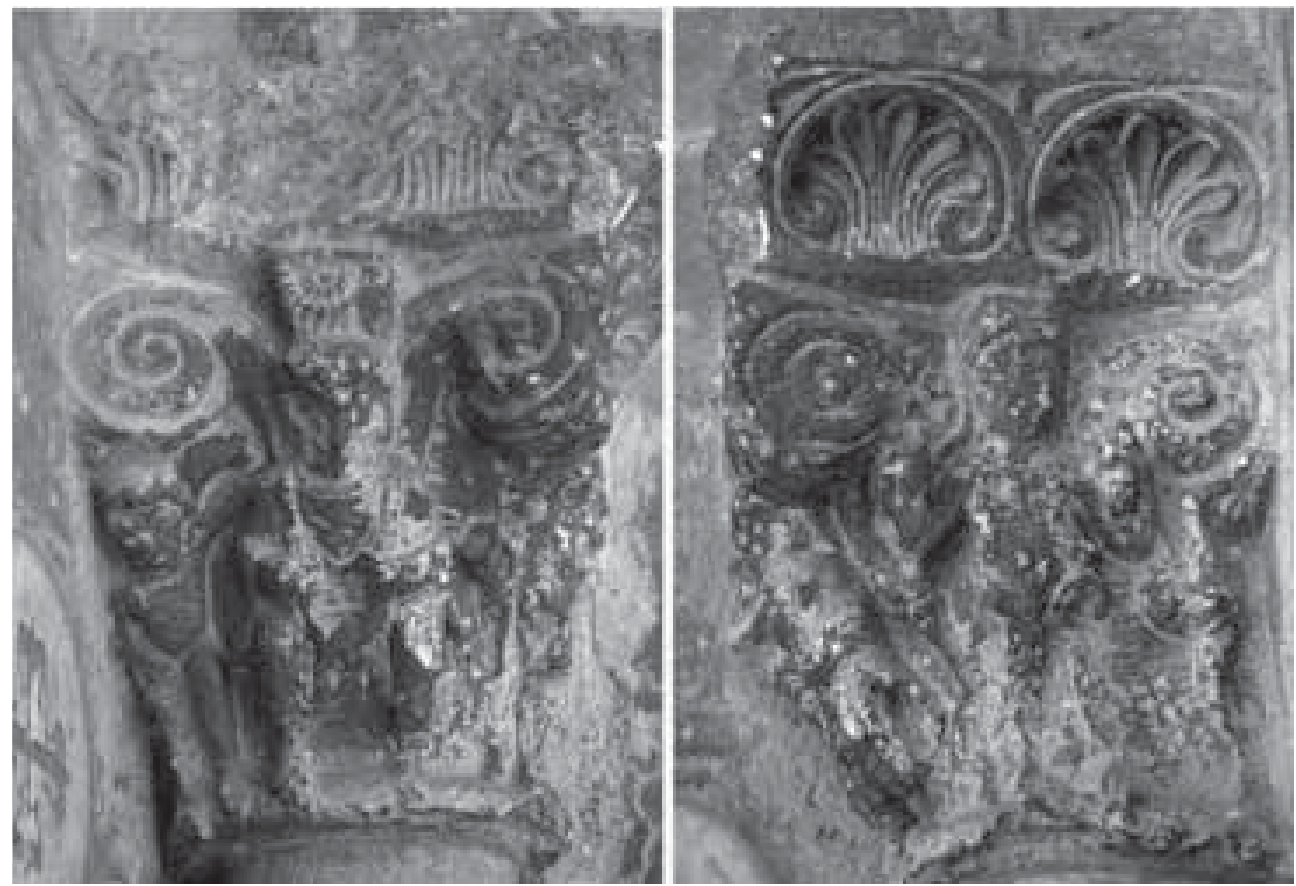

Fig. 11. Dueñas. Monasterio de San Isidro. Portada Occidental. Jamba derecha. Capitel con Avaricia y Lujuria.

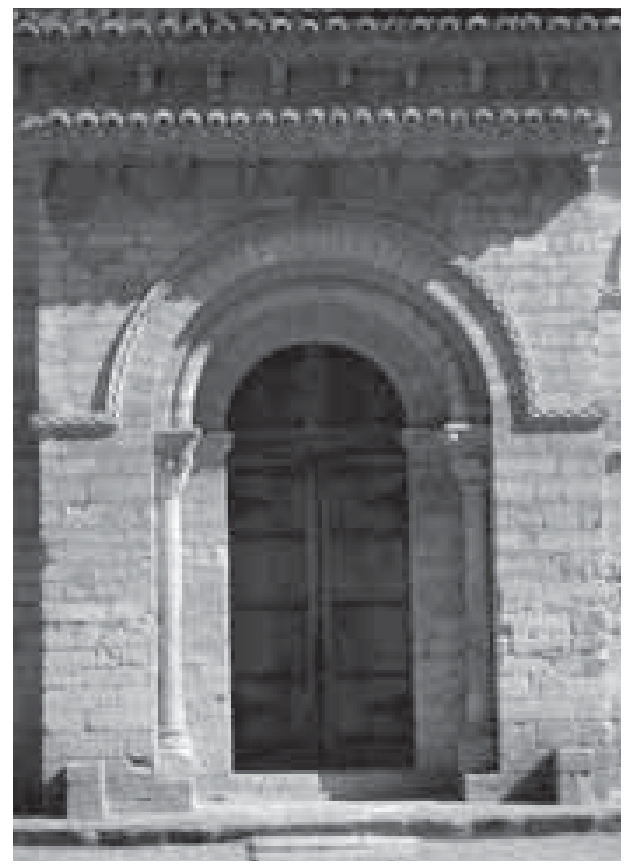

Fig. 12. Frómista. Iglesia de San Martín. Portada Septentrional. menzando a ser devorada por las fauces monstruosas de una bestia que se sitúa sobre él. Tanto la presencia de los demonios, como el detalle de la bolsa suspendida de su cuello, son imagen clara de la iconografía románica del avaro. A izquierda y derecha, en cada uno de los lados menores del capitel, dos figuras femeninas desnudas cuyos senos están siendo mordidos por sendas serpientes que, ascendiendo desde sus piernas, tratan de asir con las manos en un intento fallido por apartarlas. Son la imagen duplicada de la femme aux serpens; de nuevo de la lujuria.

El esquema, algo más simplificado, se repite en el capitel de la jamba izquierda de la portada norte (fig. 12), lamentablemente demasiado deteriorado como para poder fijar con precisión los detalles. A pesar de ello, no quedan dudas de cuáles son sus motivos. En la cara interior, nue- 
vamente el avaro con la bolsa al cuello y junto a un ser demoníaco que se sitúa a su izquierda. En el frente exterior, una figura sentada, presumiblemente femenina -aunque el estado de la piedra parece indicar la existencia de una barba corta-, a quien, pese a estar vestida, dos serpientes muerden en el pecho ${ }^{32}$. Otra vez la lujuria. En el vértice del capitel, una cabeza animal de fauces abiertas y amenazadoras sirve de elemento de separación entre ambos personajes (fig. 13) 33 .

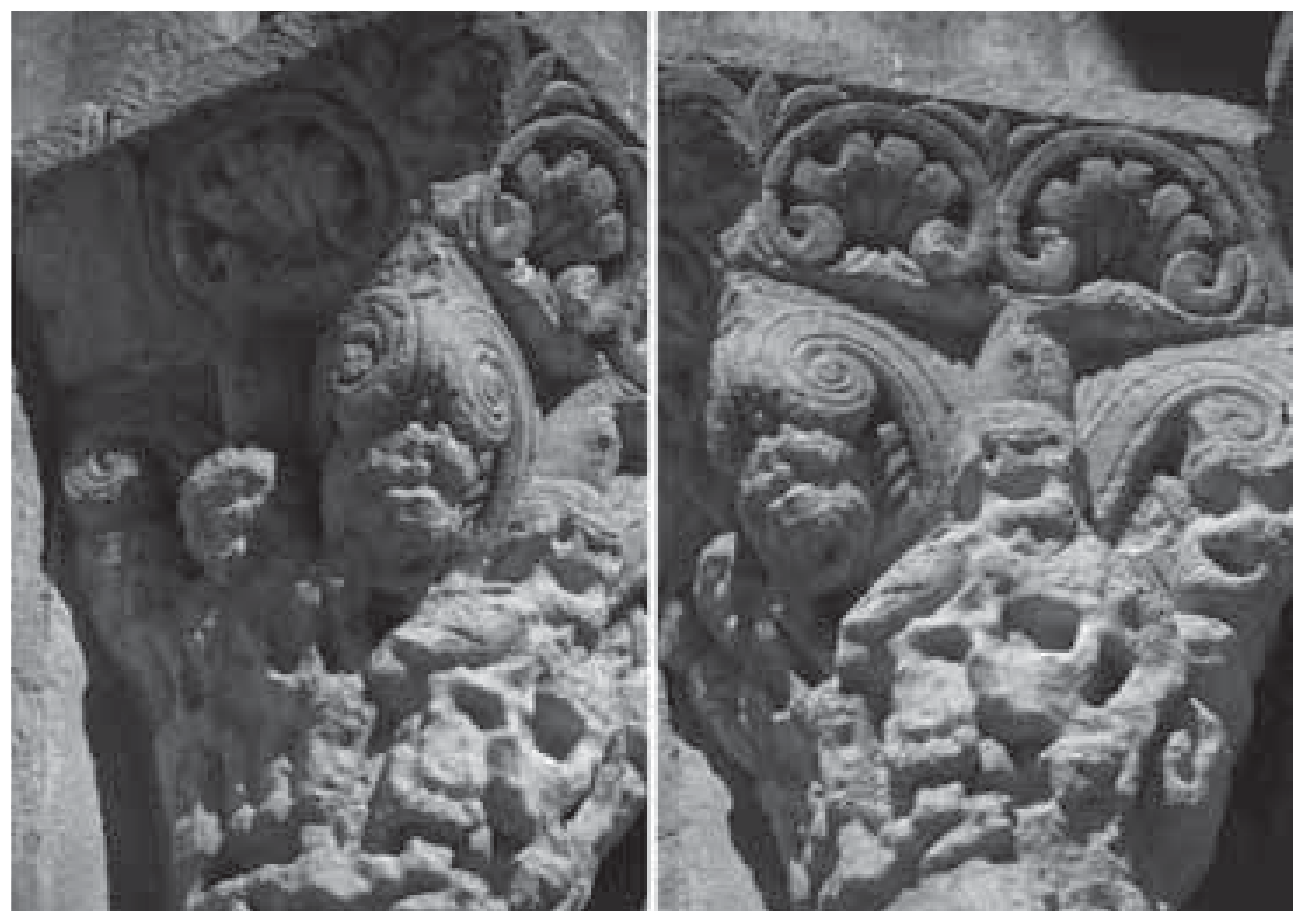

Fig. 13. Frómista. Iglesia de San Martín. Portada septentrional. Jamba izquierda. Capitel con Lujuria y Avaricia.

32 El hecho, a pesar de lo extraño, no es único; se repetirá por las mismas fechas en otro capitel del Panteón Real de San Isidoro de León en el que se efigia, igualmente, otra figura de anatomía femenina, pero de cabeza masculina y rostro barbado, a la que dos serpientes muerden los pechos: A. Gómez Gómez, El Protagonismo..., op. cit., pág. 62 y, como para toda la escultura legionense en la que el tema de la condena de los vicios se prodiga por gran parte de la basílica T. Martin, Queen as King. Politics and Architectural Propaganda in Twelfth-Century Spain, Leiden-Boston, 2006, así como su colaboración en este mismo volumen. Esta anomalía fisionómica llevó a M. Durliat, La sculpture romane de la route..., op. cit., pp. 190-191, a identificarla, no con la lujuria misma, sino con una imagen deformada de su iconograma de origen, de la Tierra Madre.

33 Aún restan en la iglesia fromestana otros esquemas que podrían, igualmente, apuntar en la dirección admonitoria contra la lujuria, como son las cestas con simios acuclillados que se muestran en alguna de las ventanas del templo. En esta dirección, véase el trabajo de T. MARTIN, "Escultura románica para un público laico: el "maestro de la Orestiada" de Frómista y sus contemporáneos", San Martín de Frómista, ¿paradigma o historicismo?, Valladolid, 2005, pp. 69-83 (pág. 74). En este mismo sentido, aunque remitiendo a conocidos ejemplos aragoneses, ya se había pronunciado S. MoraleJo, "Aportaciones a la interpretación del programa iconográfico de la catedral de Jaca”, Homenaje a Don José María Lacarra de Miguel en su jubilación del profesorado: estudios medievales, Zaragoza, 1977, vol. I, pp. 173-198. Sobre el simbolismo negativo de los simios en el imaginario medieval y en los escritos de los Padres de la Iglesia, sigue siendo obligada la consulta de H. W. JAnson, Apes and Ape Lore in the Middle Ages and the Renaissance, Londres, 1952 (reed. Nendeln/Liechtenstein, 1976). 
Ambas portadas comparten dos circunstancias básicas: la coetaneidad de sus labras y sus vinculaciones con Cluny.

Respecto al primer aspecto, y después de los estudios de S. Moralejo, se viene aceptando para estos capiteles exteriores de Frómista una cronología dentro de la última década del siglo XI (ca. 1090-1100) y por lo tanto, contándose entre algunos de los testimonios más tempranos de la escultura románica peninsular ${ }^{34}$. Para Dueñas, y aunque Antón -sin precisar por qué- supuso una data algo anterior (a partir de 1075) $)^{35}$, el análisis estilístico demuestra su dependencia formal respecto de Frómista, indicando así una fecha próxima al cambio de centuria (ca. 1100) ${ }^{36}$.

Por lo que al segundo aspecto se refiere, San Isidro de Dueñas, ya lo hemos dicho, se convierte en el primer centro cluniacense en el Reino de León, tras su donación a la abadía borgoñona por parte de Alfonso VI el 29 de diciembre de 1073. Es a partir de este momento cuando los especialistas fijan el inicio de las obras del nuevo templo románico, a cuya fachada occidental pertenecen los capiteles en cuestión.

Pasando a Frómista, lo cierto es que el cenobio no se integrará oficialmente en la federación cluniacense hasta 1118, cuando es entregado al abad de San Zoilo de Carrión. Pero teniendo en cuenta la política religiosa de los reyes castellanoleoneses del momento, y la soberanía espiritual ejercida por la casa francesa sobre

\footnotetext{
34 Como reiteró en más de una ocasión, la ejecución hacia 1093 de la lauda sepulcral de Alfonso Ansúrez, reflejo del arte de Frómista, es prueba de que por los mismos años, o incluso algunos antes, se encontraba en plena actividad el taller de San Martín: S. Moralejo, "San Martín de Frómista en los orígenes de la escultura románica europea”, Jornadas sobre el Románico en la provincia de Palencia (Palencia, 1985), Palencia, 1986, pp. 27-37 (pág. 35), e ID., “Cluny y los orígenes...”, op. cit., pág. 12. En referencia a este aspecto, y a pesar de otras propuestas que tratan de retrasar las cronologías de Frómista hasta la segunda década del siglo XII (J. L. Senra Gabriel y Galán, "Architecture et décor...”, op. cit.), Francisco Prado acaba de establecer, de forma impecable, una fecha referencial para la labor del principal escultor fromestano, el autor del denominado capitel de la Orestiada, cuya obra encuentra plena justificación a la luz de los acontecimientos que rodearon la celebración del Concilio de Husillos, en 1088: F. Prado-VILar, "Saevum facinus...", op. cit.. No es por tanto, sino a partir de esta data, cuando debió desarrollarse la labor escultórica y decorativa de San Martín, coincidiendo, con esas cronologías próximas al cambio de centuria que, por otros caminos, ya intuía Moralejo.

35 F. Antón, "San Isidoro de Dueñas...”, op. cit., pp. 138-139.

36 Filiación con el arte de Frómista reseñada por Moralejo, para quien este capitel "refleja, con cierta tosquedad, los prodigiosos desnudos en que abunda la decoración de San Martín”. Por si esto no fuera suficiente para tratar de fijar su cronología, los capiteles restantes de la misma portada, de hojas lisas rematadas en bolas, suponen a su juicio una "versión elaborada de un tipo que parece haber hecho su aparición en la catedral románica de Burgos -iniciada entre 1079 y 1081 y con culto ya en 1092- y en San Pedro de Arlanza, cuyas obras comenzaron en 1080": S. MoraleJo, "Cluny y los orígenes...", op. cit., pág. 12 (ya anunciado con anterioridad por el mismo autor en "Cluny et les débuts de la sculpture romane en Espagne", Le gouvernement d'Hugues de Semur à Cluny: actes du Colloque Scientifique International (Cluny, 1988), Mâcon, 1990, pp. 405-434, esp. 409). En fechas recientes, J. L. Hernando ha subrayado la importancia de los capiteles de Frómista y Dueñas como algunos de los testimonios más tempranos del tema en la escultura románica peninsular: J.L. Hernando Garrido, "La representación del diablo en la escultura románica palentina", El Diablo en el Monasterio. Actas del VIII Seminario sobre Historia del Monacato (Aguilar de Campoo, 1-4 agosto, 1994). Codex Aqvilarensis, no 11 (1996), pp. 175-214 (esp. 209).
} 
las principales comunidades de Tierra de Campos, parece más que posible que el monasterio de San Martín viviese ya bajo los usos cluniacenses aún antes de su incorporación formal a la Orden.

Llegados a este punto, tal vez sea el momento de retomar, por un momento, la decoración hipotética de la desaparecida portada norte de San Zoilo, en la que quizás podría presuponerse una representación de los castigos como las que venimos analizando para Frómista y Dueñas. No sólo por ubicarse como ellos en esa zona privilegiada de colonización cluniacense que es la Tierra de Campos palentina Mesopotamia entre el Cea y el Pisuerga, tal y como denominó al área Bishko-. Ni porque sus tallas se integren dentro de la misma corriente estilística que las anteriores y dentro de un mismo período cronológico. Si no, y lo que es más importante, porque en la donación a Cluny de San Zoil se incluye un fragmento significativo en el que se hace alusión expresa al tormento que aguarda a quienes se preocupen por atesorar bienes y luego no ejerzan la caridad con los pobres que se topen en su camino o acudan a ellos pidiendo auxilio: quoniam pauperes in sua paupertate deficiunt; de divitibus scriptum est: quia thesaurisant et ignorant cui congregant ea et iterum audivimus: quia potentes potenter tormenta patiuntur. Por aventurar una hipótesis, nada más conveniente que el que un relieve figurando el castigo del avaro, tal vez acompañado por el de la lujuria, hubiera sido tallado en alguno de los capiteles del primitivo ingreso septentrional ${ }^{37}$.

Estas coincidencias no tendrían mayor trascendencia si no fuera porque la conexión benedictina parece ser una constante que se repite en todos los edificios del período en los que encontramos representadas a lujuria y avaricia, y afectando a cualquier campo de las artes plásticas. Así lo hemos visto ya en la miniatura del Infierno de Silos; hasta en cuatro ocasiones en San Isidoro de León, centro que, aunque nunca estuvo regido por los monjes negros, estuvo estrechamente vinculado a ellos a través de la relación establecida entre la dinastía reinante y la Casa Madre; o en un capitel de la portada de Santa María de Iguácel, posterior al año 1080 en el que la ermita aragonesa es entregada a los monjes de San Juan de la Peña. En Navarra, tampoco faltarán en la más tardía Porta Speciosa del monasterio de Leire. ${ }^{38}$

Y hemos dejado para el final el ejemplo que seguramente preceda a todos los demás cronológicamente y el que conserva en su iconografía una deuda más estrecha con los prototipos clásicos. Me refiero a la representación de la lujuria que decora un capitel colocado entre la capilla de El Salvador y la de San Pedro, en la cabecera compostelana (fig. 14), fiel trasunto pétreo de una ilustración de Tellus contenida

37 Sobre el fragmento citado, llamó la atención S. Moralejo, “Cluny y los orígenes...”, op. cit., pp. 23-24, habiendo sido recientemente reproducido por J.L. HERnANDo GARRIDO, "La representación del diablo...", op. cit., pág. 209.

38 MaF. Cuadrado Lorenzo, "Tres esculturas de Leire y sus relaciones con temas escatológicos", Príncipe de Viana, nº 199 (1993), pp. 229-245 y E. Aragonés Estella, La imagen del mal en el románico navarro, Pamplona, 1996 (passim). 


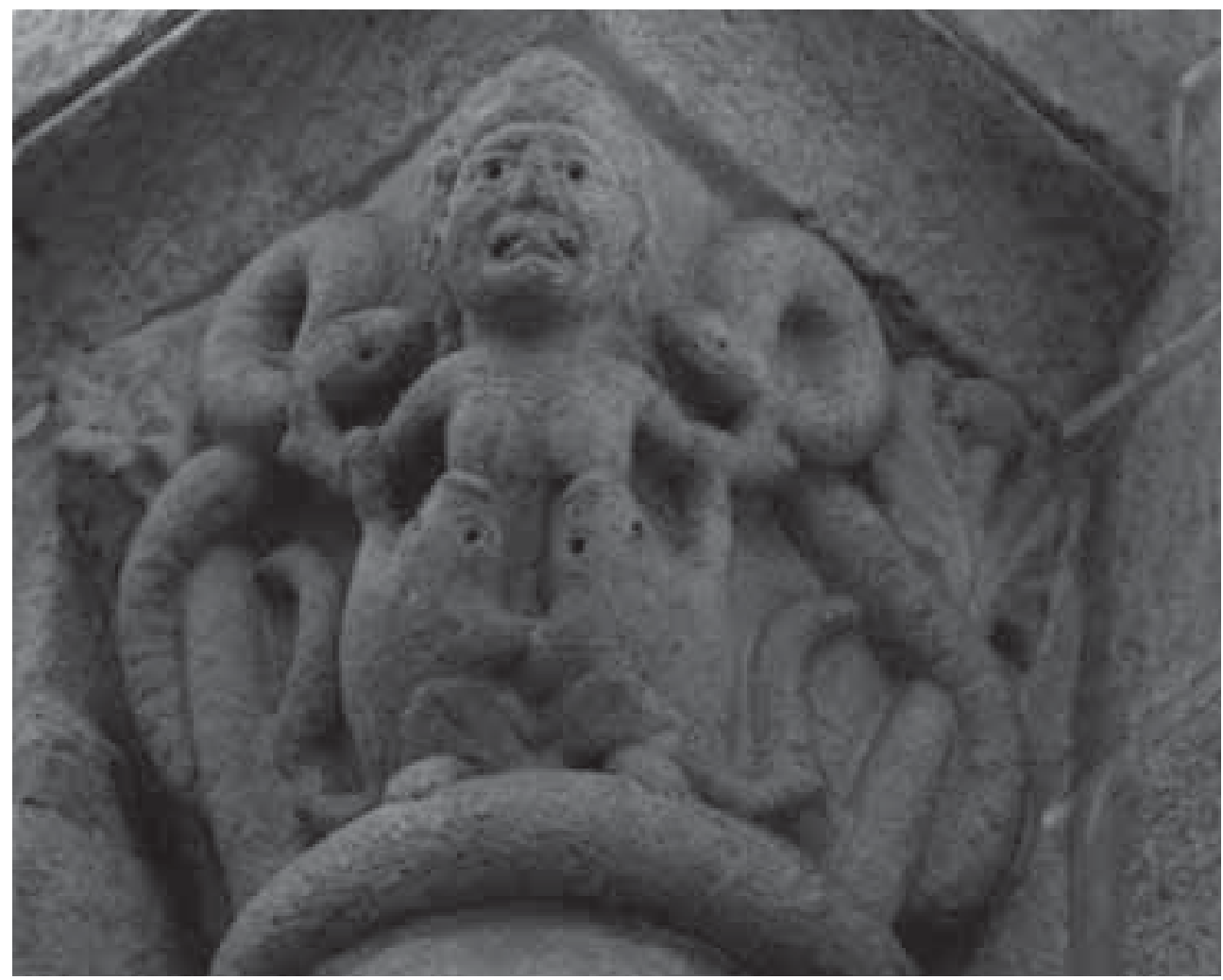

Fig. 14. Santiago de Compostela. Girola. Capitel de la Lujuria (Foto A. García Omedes).

en el Exultet de Desiderio de Montecassino (tercer cuarto del s. XI), tal y como ha desvelado Victoriano Nodar ${ }^{39}$. Y como el resto de imágenes que lo rodean, entre las que abundan los temas con finalidad moralizante extraídos tanto del bestiario, como de la iconografía clásica y de la propia figuración del momento, tuvo como destinatarios, no a supuestos peregrinos -dado el lugar-, sino a los monjes de la vecina comunidad de Antealtares, propietarios de este sector de la girola en virtud de lo dispuesto en la Concordia de Antealtares (1077). ${ }^{40}$

La circunstancia se repite igualmente al otro lado de los Pirineos. Lujuria y avaricia encuentran también su lugar, antes de acabar la undécima centuria, en la Porte des Comtes de Saint-Senin de Toulouse (ca. 1080) ${ }^{41}$, más o menos por las mismas fechas

39 V. NodAr, "De la Tierra Madre a la Lujuria...", op. cit.

40 Ibíd. e ID., Los inicios de la catedral románica de Santiago: el ambicioso programa iconográfico de Diego Peláez. Santiago de Compostela, 2004 y "Obispo, Rey y monasterio, una nueva lectura del programa de la cabecera de la Catedral de Santiago de Compostela”, en Il Medioevo. La Chiesa e il Palazzo. Atti del Convegno internazionale di studi (Parma, 2005), Milán, 2007, pp. 484-490.

41 Q. CAZEs y D. CAZES, Saint-Sernin de Toulouse: de Saturnin au chef-d'oeuvre de l'art roman, Graulhet (Tarn), 2008. 
en las que Guillermo IV, conde de Toulouse, a causa de graves diferencias con los canónigos de Saint-Sernin, los expulsa del santuario poniendo en su lugar a monjes de Moissac (1082). La situación se regularía antes de acabar el siglo con la vuelta de los canónigos, que adoptaron la Regla de San Agustín ${ }^{42}$. Algo después, ambos temas recibirán la que tal vez sea su mejor interpretación monumental en el porche meridional de la propia iglesia abacial de Moissac ${ }^{43}$, benedictina nuevamente, como también lo fue la gran abadía de Conques, en cuyo tímpano volvieron a quedar plasmados no más tarde de la primera década del siglo XII, formando parte ahora de un discurso mucho más amplio en el que junto a lo escatológico cobraba relevancia el relato hagiográfico ${ }^{44}$.

En el extremo opuesto, la situación no es la misma en los templos parroquiales -e incluso catedralicios-, en los que lujuria y avaricia, según el esquema representativo clásico, tardarán en ser incorporadas a la decoración de sus portadas. Habrá que esperar prácticamente a mediados del siglo XII para encontrar la figuración del castigo del avaro formando parte del programa iconográfico de la portada meridional de Santa María de Carrión de los Condes ${ }^{45}$; o a las serpientes atormentando tanto al lujurioso, como a la lujuriosa, entre los restos decorativos que debieron tallarse para formar parte, tal vez, de la primera portada occidental de la catedral de Santiago ${ }^{46}$.

42 M. Durliat, Saint-Sernin de Toulouse, Toulouse, 1986, pp. 12-13. Y aunque la implantación benedictina en Saint-Sernin no hubiera llegado a hacerse efectiva, que los dos monasterios más importantes de la ciudad en esos momentos, Saint-Étienne y La Daurade, fuesen cluniacenses, tuvo que marcar el panorama religioso e ideológico del resto de las comunidades regulares tolosanas. Incluso Isarno, obispo de Toulouse en 1071, e impulsor de las obras de Saint-Sernin, fue un decidido partidario cluniacense: W. WEISBACH, Reforma religiosa..., op. cit., pág. 92.

43 Relieves recientemente reinterpretados por I. H. Forsyth, "Narrative at Moissac: Schapiro's Legacy", Gesta, XLI/2 (2002), pp. 71-93, trabajo en el que también se insiste en las implicaciones monásticas que se desprenden de las imágenes.

44 Para una puesta al día en el proceso de revisión de las cronologías de la gran portada de Conques, así como de su relación plástica con Platerías: M. CAstiñEIRAS, "Da Conques a Compostella: retorica e performance nell'era dei portali parlanti”, Medioevo: immagine e memoria. Atti del Convegno internazionale di studi (Parma, 23.28 settembre, 2008), Milán, 2009, pp. 233-251 e ID., "Didacus Gelmirius, patrono de las artes. El largo camino de Compostela: de periferia a centro del Románico”, en Compostela y Europa. La historia de Diego Gelmírez, Milán, 2010, pp. 32-97, así como en la ficha para la misma obra "Capitel con David y sus músicos de Sainte-Foy de Conques", Ibíd., pp. 324-325.

${ }^{45} \mathrm{Y}$ aunque presente en un templo parroquial, no deja de llamar la atención que el personaje luzca una evidente tonsura remitiendo, de nuevo, al estamento eclesiástico, en la que es una de las pocas representaciones directas de la simonía tan perseguida por los reformadores: M ${ }^{\mathrm{a}}$ F. CuAdrado Lorenzo, "La iglesia de Santa María de Carrión de los Condes y su programa escultórico", Publicaciones de la Institución Tello Téllez de Meneses, no 57 (1987), pp. 203-292 (pp. 233-234) у A. Gómez Gómez, El Protagonismo..., op. cit., pág. 47. Según ambos, la imagen podría formar escena única con la figura efigiada en la dovela anterior en la que un hombre porta en sus manos un objeto circular, quizás el platillo de una balanza, en alusión al oficio de mercader, uno de los más denostados en la época.

46 Se trata de dos fragmentos de arquivolta, seguramente complementarios, en los que se refleja con gran crudeza y realismo el tormento de dos lujuriosos, hombre y mujer, ambos desnudos. Mientras los senos de la mujer son mordidos por dos serpientes que se enredan entre sus piernas y que ella trata de arrancar con las manos, en la parte superior, una cabeza monstruosa de dragón le muerde la lengua, suplicio -en principio- destinado a los blasfemos. En el otro resto, otra serpiente de gran envergadura desciende desde la cabeza del varón, cruzándole el pecho, hasta morder sus testículos. A la vez, y desde la parte inferior, lo que parece ser un sapo 
¿Quiere esto decir que los laicos estaban exentos de la crítica eclesiástica hacia su conducta moral? En modo alguno ${ }^{47}$. Y ahí está, a modo de ejemplo, el canecillo berciano de San Esteban de Corullón, en el que una figura masculina que muestra su sexo, sostiene con la mano izquierda una bolsa en lo que supone una imagen condensada de los dos vicios juntos ${ }^{48}$. Sin embargo, esta no es la norma habitual.

Por lo general, y frente a la vertiente escatológica que muestran estas escenas en las portadas monásticas donde lo que se representa es el castigo con la amenaza del Juicio y del Infierno, en los templos parroquiales y pequeñas ermitas se prefiere figurar el delito mismo, no su condena, con un significado no tanto punitivo como admonitorio y moralizador. Es la diferencia semántica que existe entre el "no debéis hacer" o "no hagáis esto ni aquello", y el "esto es lo que os espera si cometéis tal o cual pecado". Para tal fin se eligen motivos claros y directos, identificables sin dificultad alguna por todos, y que no dejen lugar a duda en el pensamiento de los que los contemplen. Este es el sentido de imágenes como parejas besándose, exhibicionistas que muestran con total descaro sus genitales, personajes itifálicos o escenas de acoplamiento ${ }^{49}$.

Y a todo ello debe sumarse otra diferencia fundamental. Este tipo de imágenes, por lo demás prácticamente inexistentes en estos primeros momentos, rara vez se emplazan en el ámbito de las portadas, sino que quedan relegadas a zonas más o menos marginales como los canecillos de las cornisas ${ }^{50}$. En su lugar, capiteles y arquivoltas -cuando éstas empiecen a aparecer- mostrarán preferentemente temas bíblicos, con un protagonismo destacado de los episodios del Antiguo Testamento.

Con lo expuesto hasta el momento, todo parece apuntar hacia la posibilidad de considerar estas representaciones de lujuria y avaricia como propias y originarias

gigantesco asciende para prenderle el pene: J. Yarza Luaces, "Castigo de los Lujuriosos", Galicia no tempo. Monasterio de San Martiño Pinario, Santiago de Compostela, 1991, pp. 189-190, $\mathrm{n}^{\circ}$ cat. 79 (con bibliografía previa sobre las piezas así como las distintas interpretaciones que se han formulado sobre su posible destino).

${ }^{47}$ Para una aproximación a lo que reflejan los penitenciales de la época sobre la educación sexual del pueblo vid.: O. Giordano, Religiosidad popular en la Alta Edad Media, Madrid, 1983, pp. 188 y ss., y A. GuREvich, Medieval Popular Culture: Problems of Belief and Perception, Cambridge/Nueva York, 1988, pp. 93-94.

${ }^{48} \mathrm{M}^{\mathrm{a}} \mathrm{C}$. Cosmen Alonso, Dos iglesias románicas del Bierzo: San Miguel y San Esteban de Corullón, León, 1985, pág. 90, y A. Gómez Gómez, El Protagonismo..., op. cit., pág. 48.

49 Opinión frontalmente opuesta -y no compartida en modo alguno por nosotros- es la manifestada por $\mathrm{M}^{\mathrm{a}}$ Ángeles Menéndez para quien estos temas, lejos de ser representaciones del pecado, son consecuencia directa de la manera de pensar y vivir de las gentes del medievo y, por lo tanto, manifestaciones iconográficas de todo un ciclo vital en el que se representaban el nacimiento, la muerte y la resurrección o regeneración de la vida, todo ello dentro de un contexto festivo que, en ocasiones, llegaba hasta a formar parte del entramado litúrgico del momento: MáÁ. MenÉNDEZ GuTIÉRREZ, "Un mito en piedra: la sexualidad en el contexto religioso de la Iglesia", Espacio, Tiempo y Forma. Serie VII, Historia del Arte, nº 11 (1998), pp. 43-66. Mucho menos nos convence lo vertido por P.-L. GianNerinI, Amour et érotisme dans la sculpture romane, Cahors, 2009, quien hace depender este tipo de imágenes en el norte peninsular de una necesidad social de repoblar el territorio rápidamente tras el avance de la Reconquista, exaltación de la sexualidad y de la fertilidad no sólo no condenada, sino directamente promovida e inducida por medio de las tallas, por los propios clérigos locales.

${ }^{50}$ Las mejores series del momento en territorio castellanoleonés, una vez más, pertenecientes a edificios monásticos: Frómista y San Pedro de Tejada. 
del mundo claustral, como una muestra evidente de lo que podríamos denominar iconografía monástica. Haciendo bueno el comentario de San Bernardo referente a la diferencia entre las necesidades del clero regular y del secular, parece que la prioridad de los iconógrafos medievales a la hora de dictar el programa figurativo de un templo parroquial estaba más en la urgencia por fijar determinados dogmas y doctrinas, que en la necesidad por corregir ciertos comportamientos. La relación se invierte cuando se trataba de la decoración de un cenobio. Se asume que los monjes conocen ya la Historia Sagrada y las verdades fundamentales de la fe; o que, al menos, pueden aprenderlas leyendo las Escrituras. De esta forma, su lugar es ocupado por otro tipo de imágenes, más crípticas, en las que lo que se insiste es en el modelo de conducta que deben seguir para asegurarse la salvación de su alma; recordatorio, por otra parte, de las disposiciones canónicas condenando simonía y nicolaísmo ${ }^{51}$.

Este planteamiento entra en franca contradicción con el defendido en su día por Meyer Schapiro. Desde que el investigador norteamericano afirmara que la multiplicación figurativa de ambos vicios no era sino un reflejo de los cambios socioeconómicos que estaba sufriendo el mundo medieval (en el que los pecados feudales por excelencia, soberbia y orgullo, característicos de una sociedad dominada por señores y monjes que tenían en la propiedad de la tierra su patrimonio, eran súbitamente sustituidos por lujuria y avaricia, testimonio de una sociedad menos agraria y más comercial) ${ }^{52}$, no son pocos los autores que han seguido su estela al considerar ambos vicios como la prueba más palpable de una secularización social $\mathrm{y}$, por tanto, al margen de las esferas religiosas ${ }^{53}$.

51 En otra línea, Therese Martin considera que, aunque dirigidas por los religiosos, su finalidad es el ejemplo moralizante para los laicos. Afirma que "los monjes al entregarse a la comunidad hacían una promesa triple a la castidad, la pobreza y la obediencia. Tenían muy presente a lo que habían renunciado, y no nos puede sorprender que quisieran que los demás también rechazaran estas tres grandes tentaciones", indicando, asimismo, que la colocación exterior de estos programas buscaría interpelar a los seglares y "no sólo a los religiosos, que se fijarían más en el interior": T. MARTIN, "Escultura románica para un público laico...”, op. cit., pp. 73 y 72 . No refiriéndose exclusivamente al tema de la lujuria y la avaricia, aunque sí de un modo más amplio a la representación de los vicios y al discurso sobre el sexo en la iconografía románica, Manuel Castiñeiras llama a la prudencia advirtiendo que el problema ni puede, ni debe ser formulado como una cuestión general fácilmente extrapolable sino a partir de su propia configuración como discurso en cada caso concreto: M. CASTIÑEIRAs, "A poética das marxes: Bestiario, fábulas e mundo ó revés”, Pagano y profano..., op. cit., pp. 293-334 (pág. 301)

52 M. Schapiro, "Del mozárabe al románico...”, op. cit., pp. 49-50.

53 Véase L. K. Little, "Pride Goes before Avarice: Social Change and the Vices in Latin Christendom", The American Historical Review, 76/1 (1971), pp. 16-49, en el que cita un fragmento de los Moralia in Job de Gregorio Magno en el que se ordenan los pecados capitales comenzando por el Orgullo, origen de todo pecado, y en cuya relación la avaricia ocupa el quinto lugar mientras que la lujuria queda relegada al séptimo y último; y J. Le Goff, La Bolsa y la Vida. Economía y religión en la Edad Media, Barcelona, 1987. Por lo que se refiere al campo de la plástica peninsular, en la misma línea se orientan ciertos planteamientos de S. MorALEJO, "Artistas, patronos y público en el arte del Camino de Santiago", Compostellanum, XXX (1985), pp. 395-430 (pp. 421 422), y el trabajo de Ma del P. CARrillo Lista, y J. R. Ferrín GonzÁlez, "La figura de la mujer con serpientes...", op. cit. Una inversión en la relación, es la manifestada en un sermón de Étienne Langton, maestro de Teología en París hacia 1180, en el que se exponía que Duo sunt que ducunt hominem ad infernum: avaritia et luxuria. Avaritia consistit in usura, rapina, simonia, furto et huiusmodi. Luxuria in victu, vestitu, coitu... Hec due, scilicet avaritia et luxuria, sunt causa omnium malorum: J. LONGĖRE, Oeuvres oratoires de maîtres parisiens au XII 
Lyman llegará todavía más lejos al considerarlos motivos -estrictamente- profanos (de creación paralela a aquéllos otros ideados por el arte oficial, es decir, monástico), vinculados en su origen al fenómeno cultural que se desarrolló en torno a las peregrinaciones a Santiago, y que no cobrarán significación religiosa por sí mismos, sino que, para ello, será necesario integrarlos dentro de un programa iconográfico más ambicioso en el que se desarrolle una narración sagrada ${ }^{54}$.

Sin embargo, no es sólo que los primeros testimonios datados pertenezcan a monasterios reformados, sino incluso la tipología misma de las representaciones nos remite al ambiente ideológico monacal ${ }^{55}$. El avaro suele ser en la mayoría de los casos hombre; la lujuriosa prácticamente siempre mujer. Es en la postura adoptada por los monjes hacia la mujer, rigurosa y misógina, donde debemos buscar la fuente ideológica de este tipo de representaciones, fundamentalmente de la del castigo de la lujuria $a^{56}$.

La mujer es la descendiente de Eva, causante de la caída del hombre en el Paraíso, y por lo tanto inductora del pecado a lo largo de toda la historia de la Huma-

siècle. Étude historique et doctrinale, 2 vols, París, 1975, (vol. II, pág. 150, nota 90). Pero, lejos de dar la razón a las presunciones de Schapiro, el auditorio más probable de esta prédica no serían los laicos sino, nuevamente, clérigos, monjes, prelados y estudiantes de Teología (ibid., vol. I, pág. 29).

${ }_{54}$ T. W. Lyman, "Motif et narratif: vers une typologie des thèmes profanes dans la sculpture monumentale de las Romerías", Cahiers de Saint-Michel de Cuxa, no 10 (1979), pp. 59-78. El tema ha sido tratado de nuevo no hace tanto por Marco Burrini para quien es necesario diferenciar claramente entre un arte sacro, dictado por los poderes eclesiásticos del momento, y un arte profano que, con independencia de una posible finalidad doctrinal o moralizadora, emana directamente de la voluntad de los fieles que eligen mostrar su esencia religiosa a través de temas evocadores de su propia naturaleza profana. Para el investigador, muchos de estos motivos hunden sus raíces en la tradición islámica que dominó la Península Ibérica desde el 711. Por ello tendrán gran eco en la escultura románica castellana. La vía jacobea será el canal transmisor que facilitará su rápida difusión al resto de los territorios: M. BURRINI, "Le sacré et le profane sur la voie des pèlerins", Cahiers de Saint-Michel de Cuxa, XXXI (2000), pp. 97-110. Los peregrinos son también para Williams los destinatarios de la advertencia contra los peligros del pecado y su castigo que se trabajó en la Porte des Comtes: J. Williams, "Framing Santiago", Romanesque Art and Thought in the Twelfth Century. Essays in Honor of Walter Cahn (C. HourIHANe, ed.), Princeton, 2008, pp. 219-238 (pág. 228). Dirigiendo el punto de vista hacia el papel que podría haber jugado en todo este asunto el mundo andalusí: I. MonTEIRA ARIAS, "Las formas del pecado en la escultura románica castellana. Una interpretación contextualizada en relación con el Islam", Codex Aqvilarensis, no 21 (2005), pp. 48-83, así como en su Tesis Doctoral La escultura románica hispana y la lucha contra el Islam (mediados del siglo XI a mediados del siglo XIII), Madrid, Universidad Carlos III, 2010, disponible en red en la dirección http://e-archivo.uc3m.es/handle/10016/8178.

${ }_{55}$ Algo que puede deducirse ya en el trabajo clásico de Weisbach, según el cual, los cluniacenses se esforzaban en despertar y agudizar en los hombres la conciencia de la culpa y el pecado, provocándoles así a la humildad, contrición y penitencia. Para ello, en sus sermones y en sus escritos acudían al medio de representar con entrañable claridad el proceder pecaminoso y los castigos y tormentos del infierno, que amenazaban por el Juicio Final del Señor: W. WeisBach, Reforma religiosa..., op. cit., pág. 87. Las alusiones a lujuria y avaricia como creaciones vinculadas a centros monásticos, así como el análisis de los principales conjuntos franceses en los que se muestran, se desarrollan en su trabajo a lo largo de múltiples páginas.

${ }_{56}$ Como así lo han contemplado ya J. SAugnieux, "Culture religieuse et culture profane...”, op. cit., y J. YARZA LuACES, "De «Casadas, estad sujetas a vuestros maridos, como conviene en el Señor» a «Señora, soy vuestro vasallo, por juramento y compromiso»", La imagen de la mujer en el arte español. Actas de las III Jornadas de Investigación Interdisciplinaria sobre la Mujer (Madrid, 1983), Madrid, 1984, pp. 53-72, quien resume la relación entre ambos con una frase algo más que acertada: "el monje es el peor enemigo de la mujer a quien utiliza como chivo expiatorio de sus propios fantasmas" (pág. 54). 
nidad $^{57}$. Para algunos autores llegarán a convertirse, incluso, en la encarnación del Mal por excelencia, en la imagen misma del demonio, que se aparecerá al monje para tentarlo in specie mulieris ${ }^{58}$. En este sentido, tal vez estuviera en la mente de Pedro de Poitiers la imagen del castigo de la mujer, atacada por serpientes, cuando describe el destinado al mismísimo Satán:

El rey del infierno será mordido por siete serpientes:

la primera es la separación constante de Dios,

la segunda, la condena eterna del Juez,

la tercera, la privación perpetua de la visión divina,

la cuarta, la pérdida definitiva de la recompensa,

la quinta, el comienzo de una pena sin fin,

la sexta, el abatimiento miserable de los amigos

la sexta, la exaltación de los enemigos ${ }^{59}$

Por ello es necesario apartar al religioso y al clérigo de su compañía. Para lograrlo, nada mejor que una descripción de la fisiología femenina como la que hace Odón de Cluny, repulsiva cuando menos:

La belleza del cuerpo está sólo en la piel. Pues si los hombres viesen lo que hay debajo de la piel, así como se dice que el lince de Beocia puede ver el interior, sentirían asco a la vista de las mujeres. Su lindeza consiste en mucosidad y sangre, en humedad y bilis. El que considera todo lo que está oculto en las fosas nasales y en la garganta y en el vientre, encuentra por todas partes inmundicias. Y si no podemos tocar con la punta de los dedos una mucosidad o un excremento, ¿cómo podemos sentir el deseo de abrazar el odre mismo de los excrementos? ${ }^{60}$.

57 Eva está en la raíz de la mayoría de los comentarios negativos sobre la mujer formulados desde los principios del Cristianismo, y a lo largo de todo el período altomedieval. Un amplio panorama sobre el particular en M. T. D’Alverny, "Comment les théologiens et les philosophes voient la femme", La femme dans les civilisations des $X^{e}$-XIII siècles. Actes du colloque tenu à Poitiers les 23-25 septembre 1976. Cahiers de Civilisatión Médiévale, XX, n 2-3 (1977), pp. 105-129 y, más recientemente, en Ma L. Melero Moneo, "EvaAve. La Virgen como rehabilitación de la mujer en la Edad Media y su reflejo en la iconografía de la escultura románica", Lambard, nº 15 (2002-2003), pp. 111-134.

58 Así aparece reflejado como advertencia a los cenobitas en los Miracula S. Bertini, escritos hacia 1123: N. Huygherbaert, "Les femmes laïques dans la vie religieuse des XI' et XII" siècles dans la province ecclésiastique de Reims", I laici nella $<<$ societas christiana $>>$ dei secoli XI e XII. Atti della terza Settimana internazionale di studio (Mendola, 21-27 agosto 1965), Milán, 1968, pp. 346-389 (pág. 349); y aún antes en la leyenda del piadoso eremita Antonio, quien había sido tentado por una de estas diablas: Sustinebat miser diabolus vel mulieris formam noctu induere, feminaeque gestus imitari, Antonium ut deciperet: cfr. W.WEISBACH, Reforma religiosa..., op. cit., pp. 150 y 227, nota 248. nota 99 .

59 Cfr. J. LongèRe, Oeuvres oratoires..., op. cit., vol. I, pp. 198-199. Para el texto latino, vol. II, pp. 151,

60 Odón de Cluny, Collationum, lib. III (cfr. A. Gómez Gómez, El Protagonismo..., op. cit., pág. 55). Esta concepción, compartida por la mayoría de teólogos de la época, comienza a ser matizada por los primeros estudios científicos sobre la fisiología femenina, siendo pioneros, precisamente, los de una mujer y monja: Hildegarda de Bingen. Una visión contrastada de ambas posturas en M. C. Pouchelle, "Le corps féminin et ses paradoxes: l'imaginaire de l'intériorité dans les écrits médicaux et religieux (XII'-XIVe siècles)", $L a$ 
O su representación plástica nunca cordial y amable - algo reservado en estos primeros momentos únicamente a la Virgen-, sino, más bien, todo lo contrario: con largas cabelleras despeinadas, muy similares a veces con las que presentan algunos demonios; desnudas, mostrando en ocasiones anatomías disformes, casi cadavéricas como en el pórtico de Moissac, aludiendo a la relación simbólica que se establece entre Amor -entiéndase carnal-y Muerte -espiritual-; y, en la mayor parte de las ocasiones, efigiadas como seductoras, como inductoras al pecado (bailarinas, contorsionistas...), causa por la que serán luego castigadas (la femme aux serpents de la que estamos hablando, como iconograma más característico $)^{61}$.

Frente a ellas, movidas únicamente por la sensualidad -y como consecuencia lógica volubles e inestables-, los hombres. Creados directamente por Dios a imagen y a semejanza suya, los varones son los únicos que están dotados de razón y por tanto de capacidad para hacer negocios ${ }^{62}$. Por ello, la avaricia es un pecado considerado exclusivamente masculino, como varones son también los condenados por usura en las representaciones escultóricas. Y aún así, en última instancia, también se responsabilizará a las mujeres de esta falta -propiamente masculina, volvemos a recordarlo-, como las que impulsarán a los hombres al robo y a la usura como medio para conseguir el dinero que pague sus caprichos y chucherías ${ }^{63}$.

En cualquier caso, para finalizar, y volviendo a la plástica de las portadas castellanoleonesas, el posible origen monástico de los motivos no implicó su total ausencia del resto de edificaciones del período. Su ubicación en los ingresos abaciales y, por lo tanto, en el exterior de los edificios -entorno público aunque se tratase de un monasterio-, posibilitó que los iconogramas fuesen contemplados y asimilados por el conjunto de fieles que, poco a poco, irán incorporándolos a las decoraciones de sus propios accesos. De forma coincidente en el tiempo, también los predicadores comienzan a asociar a los laicos con la práctica de estos pecados. Así, según Prevostin de Cremona (ca. 1140-1210): Sed etiam mortuus est Mahalon, scilicet ordo laicorum, qui pene totus deditus est avaritie et luxurie; plures, arte usurarum nefanda, pecunias cumulant, domos magnos construunt, agros et vineas multiplicant, et in momento, his relictis, descendunt ad inferna. A pesar de todo, y para los teólogos del siglo XII, este hecho no es sino consecuencia de la costumbre

\footnotetext{
condición de la mujer en la Edad Media. Actas del Coloquio Hispano-Francés (Madrid, 1984), Madrid, 1986, pp. 315-331.

${ }^{61}$ Aspectos contemplados por C. FrugonI, "L'iconographie de la femme au cours des Xe-XII" siècles", La femme dans les civilisations..., op. cit., pp. 177-188, (esp. pp. 180 y ss.), y haciendo referencia a un ámbito más limitado, pero no por ello menos valioso: M. SÁEnz RodríGuez, "La imagen de la mujer en la escultura monumental románica de La Rioja", Berceo, n 147 (2004), pp. 149-227. Con anterioridad, Weisbach había apuntado que, "desde el momento en que la unión de la mujer con las serpientes y el sapo excluía para el artista la posibilidad de un valor estético del cuerpo desnudo, trató de hacer una figura que despertase la mayor repugnancia posible": W. WeIsBach, Reforma religiosa..., op. cit., pág. 90.

${ }^{62}$ Para múltiples testimonios en este sentido, desde la Antigüedad clásica y hasta el siglo XIII, vid.: M.T. D'AlVerni, “Comment les théologiens...", op. cit.

63 J. Longère, Oeuvres oratoires..., op. cit., vol. I, pág. 401.
} 
que tienen los gentiles por imitar las acciones de los religiosos, tal y como se desprende del comentario de Pedro de Poitiers (1130-1205): ... quia hec facere solent, $<$ sacerdotes $>$ suo nos exemplo illud facere docent. ${ }^{64}$

Será en estos últimos ingresos en los que, paradójicamente, encontraremos alguna de sus mejores manifestaciones, como los avaros de las portadas de Vallespinoso de Aguilar y Rueda de Pisuerga en Palencia ${ }^{65}$, o su interpretación híbrida en el episodio de Herodes decidiendo la matanza de los inocentes de Languilla en Segovia; junto a otras materializaciones mucho más rústicas como las de los lujuriosos, hombre y mujer, de los capiteles del ingreso de Teza de Losa en Burgos.

Pero, para ello, habrá transcurrido cerca de un siglo desde que éstos hicieran su aparición en Frómista y Dueñas, centros a los que habría que considerar focos difusores de los iconos en la región ${ }^{66}$.

${ }^{64}$ Cfr. ibíd., vol. I, pág. 404 y vol. II, pág. 306, nota 12 (para la primera cita); vol. I, pág. 404; y vol. II, pág. 306, nota 13 (para la segunda). No se debe olvidar que, desde los años finales del siglo XI, se predicaba desde los púlpitos a los fieles la necesidad de vivir un cristianismo coherente, implicando a los laicos a luchar en la cruzada emprendida contra los principales vicios que afectaban a las instituciones religiosas (especialmente simonía y nicolaísmo): G. TelLENBACH, "Il monachesimo riformato ed i laici nei secoli XI e XII", I laici nella «societas christiana»..., op. cit., pp. 118-142, (pp. 138-139), y G. G. MerLo, "Religiosità e cultura religiosa dei laici nel secolo XII", L'Europa dei secoli XI e XII fra novità e tradizione: sviluppi di una cultura. Atti della decima Settimana internazionale di studio (Mendola, 25-29 agosto, 1986), Milán, 1989, pp. 197-215 (esp. 202). Expuestos como los monjes y clérigos -y no precisamente por imitación- a los mismos deseos, no debe extrañar que se elija para las parroquias de laicos, y con idéntico fin, los mismos temas que habían visto la luz en los templos abaciales.

65 Junto a éstos, el no menos conocido del pórtico de Rebolledo de la Torre.

${ }_{66}$ Por ello no es gratuito que sea en su entorno geográfico más inmediato en el que se detecta una mayor concentración de estos temas. A las ya reseñadas de la avaricia en Vallespinoso y Rueda, habría que sumar dos de los canecillos de Pozancos; las representaciones de la lujuria en un capitel de ventana de Villanueva de Pisuerga, en sendos canecillos de Dehesa de Romanos y Matalbaniega, y en la pila bautismal de Rabanal de las Llantas, todas ellas en Palencia. La influencia se extendería hasta la zona noroccidental burgalesa (Rebolledo de la Torre), y hasta los valles cántabros, lugar donde encontramos una mayor concentración de temas moralizadores en centros como Yermo o Cervatos. Su presencia comienza a ser más difusa y esporádica según nos vamos alejando del área de influencia cluniacense de Tierra de Campos, para contar con otro foco importante, ya fuera de nuestra comunidad y siempre en la segunda mitad del XII, en Navarra. Éste, que tal vez tenga su origen en la portada de Leire, tendrá su máximo desarrollo en el infierno del ingreso principal de Santa María de Sangüesa y en el de San Miguel de Estella, donde lujuria y avaricia son repetidas en múltiples ocasiones. Para un amplio catálogo en la escultura románica hispana: A. Gómez Gómez, El Protagonismo..., op. cit., pp. 23-71. Para los navarros, y además del trabajo ya citado de E. Aragonés Estella, La imagen del mal..., op. cit., remitimos a las fichas correspondientes de la Enciclopedia del Románico, con estados de la cuestión actualizados y amplias reseñas bibliográficas: C. Fernández-Ladreda AguAdé, "Sangüesa. Iglesia de Santa María la Real”, Enciclopedia del Románico en Navarra, Aguilar de Campoo, 2008, vol. III, pp. 1258-1280; J. Martínez de Aguirre, "Yesa. Monasterio de San Salvador de Leire”, Ibíd., pp. 1503-1535; y C. RÜCKERT, "Estella. Iglesia de San Miguel”, Ibíd., vol. I, pp. 488-506. Próximos a éstos, los de la Corona de Aragón quedan analizados por P. Rodríguez BARral, La imagen de la justicia divina. La retribución del comportamiento humano en el más allá en el arte medieval de la Corona de Aragón. Barcelona, U.A.B., 2003 (tesis doctoral en Internet: www.tdr.cesca.es), pp. 217-232. 